\title{
Towards a nationwide implementation of a standardized nutrition and dietetics terminology in clinical practice: a pre- implementation focus group study including a pretest and using the consolidated framework for implementation research
}

${\text { Gabriele Gäbler }{ }^{1 *} \text { D, Michaela Coenen }}^{2,3}$, Katrin Fohringer ${ }^{4}$, Michael Trauner ${ }^{5}$ and Tanja A. Stamm ${ }^{1 *}$ (D)

\begin{abstract}
Background \& Aims: In order to assure high quality of nutrition and dietetic care as well as research, the implementation of a standardized terminology, such as the World Health Organization (WHO) International Classification of Functioning, Disability and Health for Dietetics (ICF-Dietetics) is indispensable. The aim of this study was to explore the clinical practicability and applicability of the ICF-Dietetics in the field of nutrition and dietetic practice prior to the implementation in order to develop criteria (points to consider) for a targeted implementation strategy.

Methods: A focus group study including a pretest of the ICF-Dietetics was conducted. Subsequently, facilitators and barriers for a nationwide implementation of the ICF-Dietetics in clinical nutrition and dietetic practice were identified and linked to interventions (combining theory-based and group-based approach) using the Consolidated Framework of Implementation Research (CFIR) to organize and represent data and summarized in a logic model.

Results: In the pretest 55 clinical documentations which consisted of 248 different ICF-Dietetics categories were received. In four focus groups with 22 health professionals, 66 relevant higher-level themes and implementation strategy criteria (points to consider) were identified. These themes referred to all five domains of the CFIR, namely intervention characteristics, inner setting, outer setting, characteristics of individuals and implementation process and contained important barriers and facilitators that were linked to six implementation objectives as well as six context requirements and five main actors.

(Continued on next page)
\end{abstract}

\footnotetext{
* Correspondence: g.gaebler@richtiggesund.at;

tanja.stamm@meduniwien.ac.at

${ }^{1}$ Section for Outcomes Research, Center for Medical Statistics, Informatics, and Intelligent Systems, Medical University of Vienna, Spitalgasse 23, 1090 Vienna, Austria

Full list of author information is available at the end of the article
}

(c) The Author(s). 2019 Open Access This article is distributed under the terms of the Creative Commons Attribution 4.0 International License (http://creativecommons.org/licenses/by/4.0/), which permits unrestricted use, distribution, and reproduction in any medium, provided you give appropriate credit to the original author(s) and the source, provide a link to the Creative Commons license, and indicate if changes were made. The Creative Commons Public Domain Dedication waiver (http://creativecommons.org/publicdomain/zero/1.0/) applies to the data made available in this article, unless otherwise stated. 


\begin{abstract}
(Continued from previous page)
Conclusions: This study provides facilitators and barriers to be addressed when implementing the ICF-Dietetics in clinical practice and shows potential interventions based on this analysis. A nationwide implementation was mainly seen as a great advantage for enhancing quality and continuity of care and for providing comparable data. However, it requires further refinements and a multifaceted implementation strategy where the engagement of leadership of institutions plays a crucial role. These results have provided a foundation for a targeted implementation strategy to increase the success, reproducibility and comparability.
\end{abstract}

Keywords: Nutrition therapy, Dietetics, Documentation, International classification of functioning, disability and health, Focus groups, Diffusion of innovation, Implementations science, Consolidated framework of implementation research (CFIR), Barriers and facilitators, Theories

\section{Background}

Health conditions related to nutrition, such as diabetes, obesity, oncology (various kinds of cancer), gastrointestinal diseases or surgical interventions require medical nutrition therapy [1-3]. Dietitians and nutritional physicians are responsible for medical nutrition therapy. Dietitians are non-physician health professionals who deliver their interventions either to individual patients or groups of patients by applying the nutrition care process (NCP) and dietetic care process (DCP), respectively, designed to improve and standardize the consistency and quality of dietetics care [1, 4-7]. In order to facilitate high quality and consistency of care to all European citizens including cross-border interfaces, dietitians need to consistently apply the NCP or DCP with a standardized terminology all over Europe [1, 8, 9]. While some countries have already implemented a standardized terminology, several are still lacking one.

Two standardized nutrition and dietetics terminologies exist in nutrition care worldwide: (1) the well-established Nutrition Care Process Terminology (NCPT) developed by the American Academy of Nutrition and Dietetics which is exclusively a nutrition and dietetics terminology and (2) the International Classification Functioning, Disability and Health (ICF) for Dietetics (ICF-Dietetics) a derived classification of the World Health Organizations (WHO) tailored to the needs in dietetics care. The ICFDietetics was accepted by the Dutch WHO collaboration center of the WHO Family of International Classifications (WHO-FIC) Network. It was found suitable to describe concepts for the assessment, dietetics diagnoses, intervention goal setting and evaluation $[10,11]$. The ICFDietetics enlarges the ICF by adding 900 specific categories addressing nutrition and dietetics related issues and could be considered valuable regarding a potential usage in multidisciplinary team care [11]. While the applicability of the NCPT [12-15] and its implementation [13, 16-21] as well as the ICF without its extension specific to dietetics care has been evaluated [22-31], there is a lack of data on the practicability and applicability of the ICF-Dietetics in clinical dietetic practice.
In order to successfully implement complex interventions, an elaborated strategy designed to address identified barriers is recommended [32]. In that regard, Leeman et al. [33] provided a structured overview of strategies to facilitate reporting of implementation research findings and alignment to relevant theories. To use such theoretical approach and framework when conceptualizing an implementation strategy is widely endorsed [34-36], while still opposed by some scholars [37]. Nevertheless, an advantage of such a framework is that it allows researchers to use a common language to better synthesize and compare findings across settings and interventions [34, 38, 39]. In the literature, a large number of frameworks, models and theories for transferring research into practice exist which are useful for effective implementation [34, 40]. In order to select the most appropriate theoretical approach, useful information is provided in literature [40]. For example, the Consolidated Framework for Implementation Research (CFIR) [38] is based on 19 different implementation models and frameworks (e.g. the PARiHS Framework) and provides detailed and clearly defined constructs and domains for the implementation process and its context. To date, several studies have used the CFIR to identify barriers and facilitators (determinants of healthcare practice that affect the intervention) in pre-, during or post-implementation of clinical innovations [39, 41-45]. Only few studies so far, e.g. Robins et al. [44], used the CFIR prior to implementation of the clinical innovation to identify potential barriers and facilitators, although, this is recommended [38, 46, 47]. In that regard, evaluation in the planning phase allows for fine-tuning of the new concept before resources are spent on an insufficient implementation [42, 46]. Identifying barriers and facilitators of healthcare practice is one phase in the complex and multifaceted process of getting new innovations into practice. This phase is followed by linking specific tailored interventions to these determinants before applying and evaluating the intervention in practice [48-50]. The effects of tailored interventions are non-exhaustively examined [51-55]. To this end, precise descriptions to get comparable data across interventions are needed $[56,57]$. 
The aim of this pre-implementation study was to explore clinical practicability and acceptability of the ICFDietetics prior to its implementation in order to inform a targeted implementation strategy. The specific objectives were (a) to develop an application concept and educational program to incorporate the ICF-Dietetics in clinical dietetic practice, (b) to pretest the ICF-Dietetics in clinical practice by trained target users (dietitians), (c) to explore the acceptability of the ICF-Dietetics and its application concept with respect to a prospective nationwide implementation by means of focus groups, (d) to identify barriers and facilitators for the implementation according to CFIR constructs, and (e) to link interventions, theories and responsibilities to these identified barriers and facilitators in order to develop a logic model for the implementation of the ICF-Dietetics in clinical practice.

\section{Methods}

\section{Study design}

A focus group study (extreme case sampling) was conducted including a pretest of the ICF-Dietetics applied by dietitians (self-selection sampling) after having completed an educational program and using the Consolidated Framework of Implementation Research (CFIR) to organize and represent data. A flow chart of the study process with a timeline is depicted in Fig. 1.

\section{Development of the application concept and the educational program}

The application concept aiming to incorporate the ICFDietetics in clinical dietetic practice was developed for this study (GG) and builds on a previous study regarding clinical dietetic care documentation analysis [10] and the ICF-based documentation tools of the established multidisciplinary rehabilitation management approach, the ICFbased Rehab-Cycle [24, 25]. The tools (see Additional file 1), such as, the ICF-Dietetics Assessment Sheet and the ICFDietetics Categorical and Goal Profile were adapted and designed to apply within the NCP/DCP [10]. The application concept and the educational program for training of pretest participants, were established (GG) in January 2017 and validated by two academic dietitians by means of

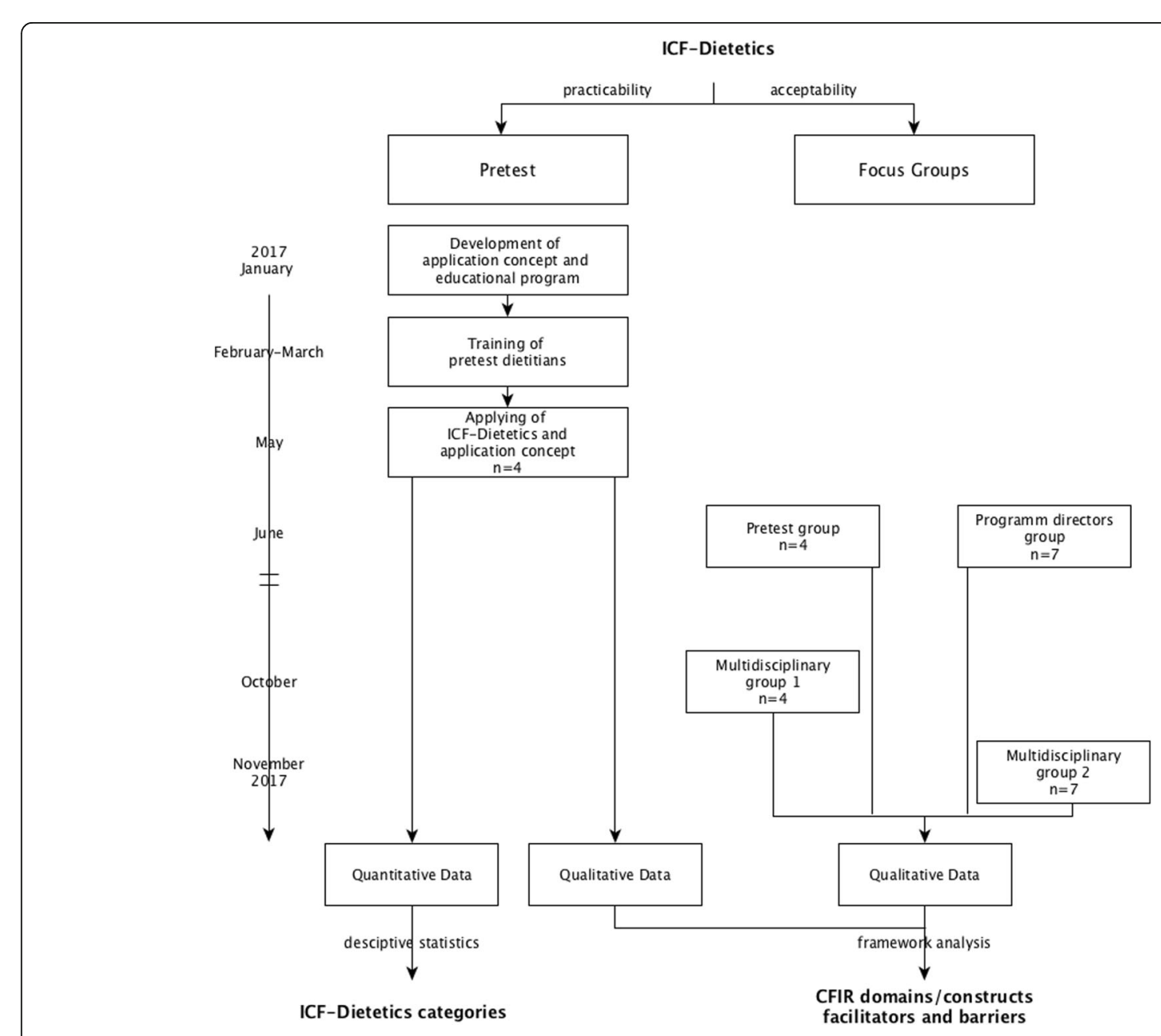

Fig. 1 Study flow chart with timeline 
cognitive debriefing using face-to-face interview. The educational program consisted of two parts, firstly of an introduction regarding the biopsychosocial model of the ICF (duration 1-2 $\mathrm{h}$ ) and secondly of a training focusing on the application of the ICF-Dietetics in clinical practice (duration 4-6h). The training was held in terms of interactive presentation and practical exercises by examples.

\section{Determine practicability of the ICF-dietetics by means of a pretest}

For this pretest, a large university hospital was chosen in which 22 dietitians (17.75 40-h full-time equivalents) are employed. Self-selection sampling was used, meaning that all 22 dietitians of this hospital were invited to the first introduction part. Five of them decided to participate in the educational training and four to apply the ICF-Dietetics for 3 weeks in May 2017 (after having applied the concept in 2-3 training patients). All four of them fulfilled the eligible criteria, such as, having clinical experience of at least 1 year and currently working in one of the most common dietetic medical areas, like gastroenterology, metabolic diseases, oncology, surgery, nephrology, intensive care, geriatrics and pediatrics. Participants of the study were provided the ICF-Dietetics in terms of a web-based version with a search function and had to achieve two aims (1) to apply the Dietetics Assessment Sheet and the ICF-Dietetics Categorical and Goal Profile (see Additional file 1) for approximately ten consultations of different medical areas and (2) to make notes about their experiences during the application phase. The qualitative notes were analyzed in a later stage of the project together with the focus group data. Descriptive statistics (absolute and relative frequencies) were used to depict the number of used ICF-Dietetics categories by medical areas. For better comparison with other studies, ICF-Dietetics categories were presented at the second level of the ICF classification. The framework of the ICF and the ICF-Dietetics, respectively, including the levels of the classification is described elsewhere $[10,11,58]$.

\section{Determine acceptability of the ICF-dietetics implementation by means of focus groups Focus group participants}

Participating experts were recruited with a purposive extreme case sampling focusing on participants with unique or special characteristics to get insight into the topic at great depth. One group was conducted with dietitians who had taken part in the pretest of the ICFDietetics. Another group included all program directors of universities for dietetics of the country, and two further groups consisted of interdisciplinary teams of physicians and health professionals who had been applying the ICF in their clinical practice. All focus groups were natural groups with established working relationships.
The participants received an introduction to the ICFDietetics, their underlying biopsychosocial model and the concept how to apply it in clinical dietetic practice (15-90 min). The pretest and program directors' groups received a more detailed introduction compared to the multidisciplinary groups. Thus, all participants of the multidisciplinary groups were familiar with the ICF and its clinical application, and therefore were only given an introduction into ICF-Dietetics and its application. Health professionals of the multidisciplinary groups were eligible if they had clinical experience of at least 1 year and had been actually working with the ICF in clinical practice. According to previous studies $[59,60]$, the focus group size was set at a maximum of seven people to enable interactions and different opinions.

\section{Data collection}

To guide the focus group sessions, semi-structured, openended questions were developed (GG) and validated by a second experienced qualitative researcher (TS). All focus groups were moderated by a trained and experienced researcher (GG) together with one assistant responsible for observing the group and taking field notes during the discussion. In all groups, the same interview schedule (see Additional file 2) was used, however, allowing flexibility. The discussion started after a brief introduction of the participants (as an "icebreaker"). The focus groups were held at the institutions of the study participants and lasted between 45 and $60 \mathrm{~min}$ (without the introduction of the ICF-Dietetics). Attention was paid to a comfortable undisturbed conversation climate. Each focus group was audiorecorded and transcribed verbatim by one researcher (KF) using defined transcript rules.

\section{Data analyses}

For this study, framework analysis (a kind of thematic analysis) was used [61, 62]. This method provides clear and transparent steps and produces a highly-structured output. As described by Keith et al. [39], two frameworks (coding templates) were applied, firstly, a framework based on intervention-specific codes, secondly, the codebook of the CFIR [63]. This framework was chosen since it offers a guide for evaluating the entire implementation process in combination with other process framework e.g. the RE-AIM framework (Reach, Effectiveness, Adoption, Implementation, and Maintenance) [38, 64, 65]. The CFIR provides a pragmatic meta-theoretical structure with a high level of operationalization across constructs and domains [40], thus enables comparison of ratings across institutions [45] and studies. Moreover, it is widely used among health care studies $[42,66]$ for evaluations in terms of guiding data collection, analysis and reporting [39, 41, 45, 67, 68]. After familiarization with the verbatim transcripts (including the qualitative notes of the pretest), the text was divided 
into segments. Segments are meaningful parts of the text that belong together and were assigned with a conceptual label (code). The first coding framework emerged from the analysis of the first focus group transcript. Each code was discussed by two researchers regarding its meaning (GG and TS). Subsequently, this thematic framework (based on codes incorporating interview background and identified theme) was applied to all documents. However, new codes were created during this analyzing process when needed. In the next step, the codes were reduced, summarized and grouped around similar and interrelated themes. While codes were closely and explicitly linked to the raw data (original text), the process of assigning higher-level themes started the abstraction of the data. This abstraction was further developed by grouping codes and corresponding higher-level themes according to the CFIR domains, constructs and sub-constructs in a spreadsheet, generating a matrix. Additionally, this matrix depicted illustrative quotations and references to whether it was mentioned as a barrier (aspects everything that restrains or hinders implementation) or a facilitator (aspects everything that makes implementation easier or enables it). Table 1 illustrates the code reduction and abstraction process in terms of an example. The assignments (barrier or facilitator) were done with regard to explicit statements of focus group participants or interpretation of the context by the consensus of all researchers (GG, MC, KF, MT, TS). Data analysis was performed using ATLAS.ti Version 8.1.3, Scientific Software Development GmbH, Berlin.

\section{Linking interventions, theories and responsibilities}

The linking of interventions and responsibilities to identified barriers and facilitators was performed in two parts: firstly, a theory-based linking exercise of focus group results and literature $[48,49,52,53,69-71]$ done by the first author (GG) and secondly, by an explorative group-based approach by different academic and/or clinical experts and authors of this study (GG, MC, KF, MT, TS). Subsequently, by merging the results according to implementation objectives and its context requirements with respect to its responsibilities, a logic model for the implementation strategy was developed.

\section{Results}

Descriptive results of the pretest

From the pretest, 55 documents (ICF-Dietetics Categorical and Goal Profiles) with a total number of 485 ICF-

Table 1 Example of framework analysis in terms of code reduction and charting process (matrix)

\begin{tabular}{|c|c|c|c|c|c|c|}
\hline \multicolumn{2}{|c|}{ Code reduction process } & \multicolumn{5}{|l|}{ Charting data into a matrix } \\
\hline $\begin{array}{l}\text { First Thematic } \\
\text { Framework }\end{array}$ & $\begin{array}{l}\text { Reduced } \\
\text { Thematic } \\
\text { Framework }\end{array}$ & CFIR Domain (construct) & $\begin{array}{l}\text { Higher-level- } \\
\text { theme }\end{array}$ & Quotation & $F^{a}$ & $B^{b}$ \\
\hline $\begin{array}{l}\text { Advantages/ } \\
\text { Strengths/ } \\
\text { Opportunities }\end{array}$ & $\begin{array}{l}\text { Advantages/ } \\
\text { Strengths/ } \\
\text { Opportunities }\end{array}$ & & & & & \\
\hline $\begin{array}{l}\text { ICF-Dietetics and } \\
\text { concept: } \\
\text { Interdisciplinarity/ } \\
\text { Multidisciplinarity }\end{array}$ & no change & $\begin{array}{l}\text { Innovation Characteristics } \\
\text { (Relative Advantage) }\end{array}$ & $\begin{array}{l}\text { Interdisciplinarity/ } \\
\text { Multidisciplinarity }\end{array}$ & $\begin{array}{l}\text { "[...] I think that is very important, that we can work } \\
\text { interdisciplinary and with other professional groups." } \\
\text { [FG2_director_26y experience] }\end{array}$ & $\mathrm{F}$ & \\
\hline $\begin{array}{l}\text { Actual use of the } \\
\text { ICF: } \\
\text { Interdisciplinary/ } \\
\text { Multidisciplinary } \\
\text { collaboration }\end{array}$ & $\begin{array}{l}\text { Actual use of the } \\
\text { ICF: } \\
\text { Interdisciplinarity/ } \\
\text { Multidisciplinarity }\end{array}$ & $\begin{array}{l}\text { Inner Setting } \\
\text { (Networks \& } \\
\text { Communications) }\end{array}$ & $\begin{array}{l}\text { Interdisciplinarity/ } \\
\text { Multidisciplinarity }\end{array}$ & $\begin{array}{l}\text { "So, we have an IT-technical network, where all } \\
\text { professional group see, if you [to the speech } \\
\text { therapist] changes something." [FG3_dietitian_18y } \\
\text { experience] }\end{array}$ & $\mathrm{F}$ & \\
\hline $\begin{array}{l}\text { Disadvantages/ } \\
\text { Weaknesses/Risk }\end{array}$ & $\begin{array}{l}\text { Disadvantages/ } \\
\text { Weaknesses/Risk }\end{array}$ & & & & & \\
\hline $\begin{array}{l}\text { ICF-Dietetics and } \\
\text { Concept: } \\
\text { Hindering } \\
\text { interdisciplinarity }\end{array}$ & $\begin{array}{l}\text { ICF-Dietetics and } \\
\text { concept: } \\
\text { Interdisciplinarity/ } \\
\text { Multidisciplinarity }\end{array}$ & $\begin{array}{l}\text { Inner Setting } \\
\text { (Networks \& } \\
\text { Communications) }\end{array}$ & $\begin{array}{l}\text { Interdisciplinarity/ } \\
\text { Multidisciplinarity }\end{array}$ & $\begin{array}{l}\text { "If the chef does not know what that is [...] it would } \\
\text { not be anything good if it would be a sole dietitian } \\
\text { thing." [FG3_physician_30y experience] }\end{array}$ & & B \\
\hline $\begin{array}{l}\text { Prerequisites for } \\
\text { Implementation }\end{array}$ & $\begin{array}{l}\text { Prerequisites for } \\
\text { Implementation }\end{array}$ & & & & & \\
\hline $\begin{array}{l}\text { Pay attention to } \\
\text { other professional } \\
\text { groups }\end{array}$ & $\begin{array}{l}\text { Interdisciplinarity/ } \\
\text { Multidisciplinarity }\end{array}$ & $\begin{array}{l}\text { Inner Setting } \\
\text { (Networks \& } \\
\text { Communications) }\end{array}$ & $\begin{array}{l}\text { Interdisciplinarity/ } \\
\text { Multidisciplinarity }\end{array}$ & $\begin{array}{l}\text { "[...] the problem of a profession-specific language is } \\
\text { [...] when it is not permeable to other professions." } \\
\text { [FG3_physician_30y experience] }\end{array}$ & & B \\
\hline $\begin{array}{l}\text { Effort of } \\
\text { persuasion on } \\
\text { multiprofessional } \\
\text { approach }\end{array}$ & $\begin{array}{l}\text { Persuading/ } \\
\text { Motivation }\end{array}$ & $\begin{array}{l}\text { Characteristics of } \\
\text { Individuals (Knowledge \& } \\
\text { Beliefs about the } \\
\text { Innovation) }\end{array}$ & $\begin{array}{l}\text { Interdisciplinarity/ } \\
\text { Multidisciplinarity }\end{array}$ & $\begin{array}{l}\text { "[...] and that's why I just believe it takes persuasion } \\
\text { that dietetics is part of the multiprofessional team. } \\
\text { [FG2_director_27y experience] }\end{array}$ & $\mathrm{F}$ & \\
\hline
\end{tabular}

${ }^{\mathrm{a}} \mathrm{F}=$ Facilitator (anything makes implementation easier or enables it)

${ }^{\mathrm{b}} \mathrm{B}=$ Barrier (anything restrains or hinders implementation 
Dietetics categories (including duplicates) were received corresponding to 248 different ICF-Dietetics categories. The detailed descriptive statistics stratified by medical areas is shown in Table 2. The list of the actual second level ICF categories is provided in Additional file 3.

\section{Focus group dynamics}

In total, four focus groups with 22 participants were conducted. Focus groups characteristics are depicted in Table 3. All participants mostly supported the use of a standardized terminology in general and the use of the ICF-Dietetics in particular. The main topic of discussion in the first pretest focus group was characterized by the positive attitude towards a common terminology on the one hand and by the difficulties in the practical application of the ICF-Dietetics on the other hand. The second focus group with the program directors was dominated by an ambitious discussion on how to implement the ICF-Dietetics nationwide in clinical practice and in education. The multidisciplinary groups (third and fourth focus group) reflected the actual clinical practice of applying the ICF in the institutions in which the participants were employed. Consequently, specific practical aspects for implementing the ICF in a daily routine within an interdisciplinary setting were discussed.

\section{Identified barriers and facilitators for a nationwide implementation of the ICF-dietetics listed by CFIR domains and constructs}

Initially, 163 codes were identified in the first thematic framework, that were reduced to 133 codes representing 66 higher-level themes, which refer to all five CFIR domains and to 21 of total 36 CFIR constructs. While in 19 constructs facilitators for a prospective implementation were identified, barriers were allocated to 11 constructs. Identified barriers and facilitators according to each domain and subordinated constructs are reported below. A summary of these findings depicts Fig. 2. Frequencies how often the topic was discussed in terms of domains/ constructs and higher-level themes, as well as derived criteria for a nationwide implementation are outlined in Additional file 4.

\section{CFIR domain intervention characteristics Evidence Strength \& Quality}

Stakeholders' perceptions of the quality and validity of evidence supporting the belief that the innovation will have desired outcomes [38, 63]. Focus group participants mentioned that it would be necessary to plan and start the implementation strategy with pilot institutions and to look at examples of other health professions or other countries. Additionally, the performed field-testing during the validation process of the ICF were discussed. (Facilitator).

\section{Relative advantage}

Stakeholders' perception of the advantage of implementing the innovation versus an alternative solution [38, 63]. Besides the implementation of the NCPT, two possibilities were brought up, namely, no standardized terminology at all or developing a completely new dietetics language from the very beginning, however, both not seen as an alternative. As main advantage of implementing the ICF-Dietetics compared to the NCPT the multidisciplinary/interdisciplinary applicability was most often mentioned. A further advantage and a facilitator for the implementation of the

Table 2 Descriptive statistic of applied ICF-Dietetics categories in respect of medical areas

\begin{tabular}{|c|c|c|c|c|c|c|}
\hline & Total & $\begin{array}{l}\text { Diabetes and } \\
\text { Metabolism }\end{array}$ & Gastroenterology & Surgery & Oncology & Others $^{2}$ \\
\hline Frequency of documents (n) & 55 & 17 & 7 & 15 & 9 & 7 \\
\hline Frequency of extracted different ICF categories (n) & $248^{d}$ & 102 & 45 & 102 & 54 & 48 \\
\hline Percentage (\%) of total concepts $n=248$ & & 41 & 18 & 41 & 22 & 19 \\
\hline Frequency of second-level ICF categories (n) & $75^{d}$ & 38 & 24 & 41 & 28 & 24 \\
\hline Percentage (\%) of total $n=75$ & & 51 & 32 & 55 & 37 & 32 \\
\hline Body Functions ( $n$ ) & $32^{d}$ & 14 & 15 & 20 & 18 & 12 \\
\hline Body Structures (n) & $5^{d}$ & 2 & 2 & 3 & 3 & 1 \\
\hline Activities (n) ${ }^{\mathrm{b}}$ & $15^{d}$ & 10 & 1 & 5 & 3 & 3 \\
\hline Participation (n) ${ }^{b}$ & $6^{d}$ & 1 & 2 & 4 & 3 & 0 \\
\hline Environmental Factors (n) & $10^{d}$ & 8 & 4 & 4 & 1 & 3 \\
\hline Personal Factors $(n)^{c}$ & $7^{d}$ & 3 & 0 & 5 & 0 & 5 \\
\hline
\end{tabular}

${ }^{\mathrm{a}}$ Other medical areas included nephrology, pediatrics, neurology

bIn contrast to the original ICF where "Activities and Participation" begins with (d), the ICF-Dietetics differentiates between "Activities (a)" and "Participation (p)" as it is also given as an alternative option by World Health Organization [58]

"ICF-Dietetics provides a first draft of codes covering "Personal Factors"

${ }^{d} \mathrm{~A}$ concept could be used in different medical areas, thus, $\mathrm{n}$ is not the sum of them 
Table 3 Focus group characteristics

\begin{tabular}{|c|c|c|c|c|c|c|c|c|c|c|c|c|}
\hline \multirow{2}{*}{$\begin{array}{l}\text { Focus } \\
\text { group }\end{array}$} & \multirow{2}{*}{$\begin{array}{l}\text { Number of } \\
\text { participants }\end{array}$} & \multirow[t]{2}{*}{ Health professions } & \multicolumn{2}{|l|}{ Gender } & \multicolumn{5}{|c|}{ Years of work experience } & \multicolumn{3}{|c|}{ Highest degree of education } \\
\hline & & & Female & Male & Median & Mean & SD & Min & $\operatorname{Max}$ & Bachelor & Master & $\begin{array}{l}\text { Medical } \\
\text { specialist }\end{array}$ \\
\hline 1 & 4 & Dietitians (pre-test) & 3 & 1 & 2 & 4.2 & 4.5 & 2 & 11 & 2 & 2 & - \\
\hline 2 & 7 & Dietitians (program directors) & 6 & 1 & 27 & 27.1 & 9.4 & 14 & 40 & - & 7 & - \\
\hline 3 & 4 & $\begin{array}{l}\text { Physician, Dietitian, Nurse, Speech and } \\
\text { Language therapist }\end{array}$ & 3 & 1 & 12 & 14.8 & 11.8 & 4 & 30 & 2 & 1 & 1 \\
\hline 4 & 7 & $\begin{array}{l}\text { Physician, Dietitian, Nurse, Speech-, } \\
\text { Physiotherapist, Linguist }\end{array}$ & 5 & 2 & 25 & 23.4 & 6.3 & 15 & 31 & 4 & 1 & 2 \\
\hline Total & 22 & & 17 & 5 & 19.5 & 19.5 & 11.5 & 2 & 40 & 8 & 11 & 3 \\
\hline
\end{tabular}

ICF-Dietetics was mentioned, is the fact that the ICF is a reference classification of the $\mathrm{WHO}$ and has no license fee. (Facilitator)

"But in principle I think, it is certainly clever not to develop a new language [...], but to apply the ICF, which is very widespread in the European area."

[FG4_physician_31y experience]

Additionally, many other general advantages (e.g. comprehensibility, comparability, standardization, professionalization etc.) compared to having no standardized terminology were discussed. For example, ICF-Dietetics with the biopsychosocial approach will facilitate structured and transparent care to gain additional information that otherwise may be missed.
Moreover, specific advantages for patients in terms of continuity of care, patient centered care and better understanding of goals were pointed out. (Facilitator).

Not many general disadvantages of the ICF were mentioned. In one group the use of a professional-specific extension of the ICF was seen as great barrier for multidisciplinary team work. Additionally, while the biopsychosocial model was partly seen as supportive, it was emphasized by one expert that the usage of this model poses a crucial barrier. (Barrier).

"This scheme with the biopsychosocial model is a major barrier in the dissemination of the ICF. Simply because body functions, activities and participation are placed on the same level. But body functions and

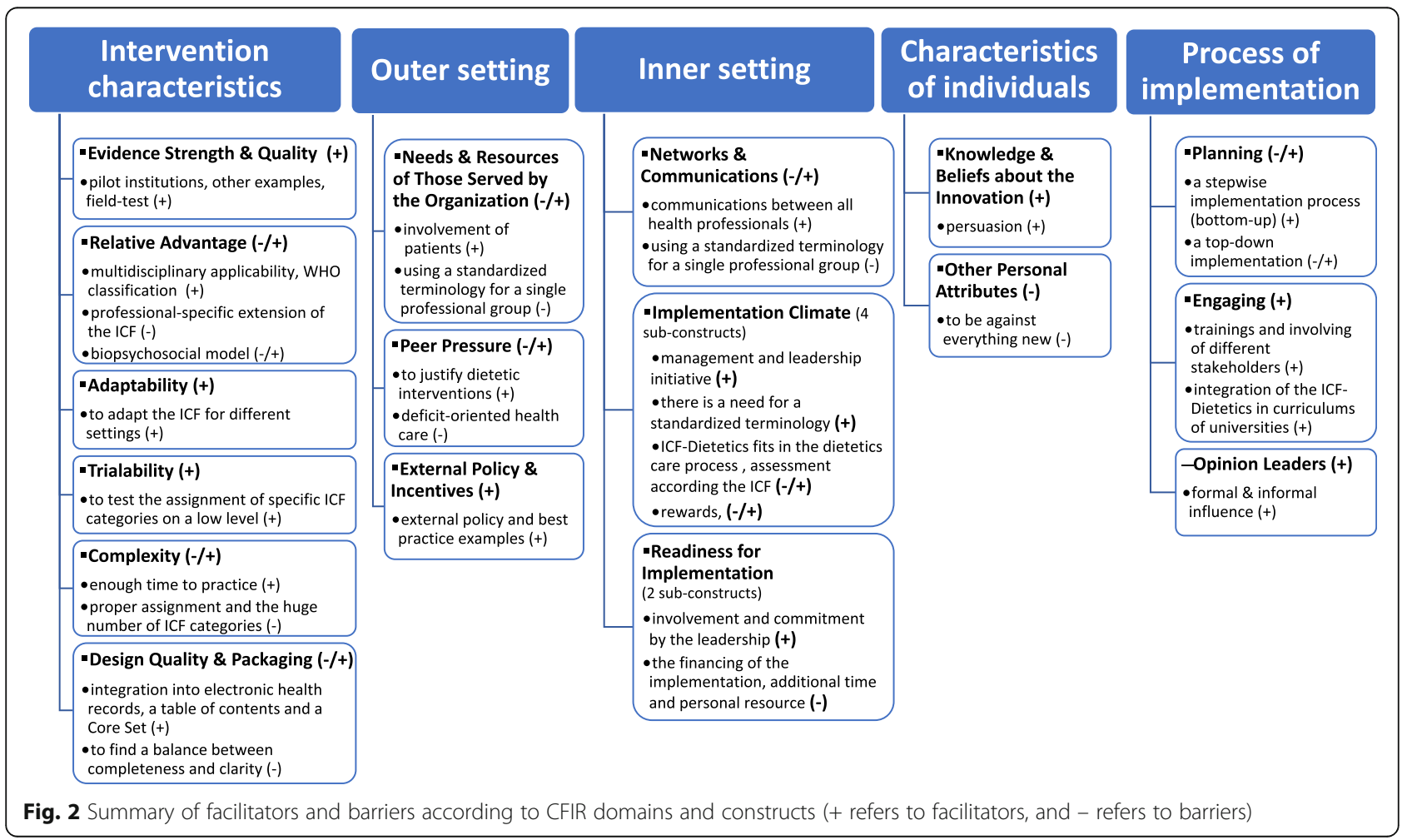


activities and participation do not belong on the same level. [...]. And putting activities and participation on the same level once again is a barrier. Because it's the question [...]: What are we looking at, can do or do?" [FG4_physician_31y experience]

\section{Adaptability}

The degree to which an innovation can be adapted, tailored, refined, or reinvented $[38,63]$. The possibility and requirement to adapt the ICF for different settings within the profession and the multidisciplinary team, were mainly discussed in the two multidisciplinary groups. Practical examples of how the ICF has been adopted in interdisciplinary settings and that it would be necessary to integrate dietitians in this team and how to integrate them were stressed. (Facilitator)

"I could imagine expanding our target catalogue to include such [dietetic] goals." [FG4_linguist_16y experience]

\section{Trialability}

The ability to test the innovation on a small scale in the organization, and to be able to reverse course if warranted [38, 63]. Discussants mentioned that it would be helpful to test the assignment to specific ICF categories on a low level prior to the implementation of the whole classification system. (Facilitator)

"[...] and the colleagues now, for example, [...] once so that they can give it a try, [...]. Not with pressure, [...] without the complex ICF system behind it." [FG2_director_36y experience]

\section{Complexity}

Perceived difficulties of the innovation [38, 63]. Enough time to practice was seen as a promotive factor to integrate the new terminology in clinical dietetic practice. (Facilitator)

\section{"[...] if you practice that [...] then that's quite possible."}

[FG1_dietitian_11y experience]

Mentioned were the difficulty of a proper assignment of intervention goals to an appropriate ICF category, as well as the use of Environmental and Personal Factors. Furthermore, several concepts were not easy to understand and needed a revision. The great amount of ICF categories and especially of the added specific dietetics categories and the effort to implement a standardized process were considered in all four focus groups. (Barrier)
"[...] because of the convolution, there is too much in there I find, so more for physical therapists or occupational therapists.”[FG1_dietitian_2y experience]; "[...] and that's actually the biggest barrier I see [...] expanding and ultimately increasing the amount [in additional ICF-Dietetics categories] and the complexity." [FG4_physician_31y experience]

\section{Design Quality \& Packaging}

Perceived excellence in how the innovation is presented, and assembled [38, 63]. As main facilitator, the application concept and the web-based search function were emphasized. Additionally, the integration into electronic health records was discussed as prerequisite for a successful implementation. In this context, having a table of contents and a Core Set with the most typical ICFDietetics categories were considered. In the pretest focus group, participants reported that several ICF categories should be checked for their necessity. (Facilitator)

"But as I said, if you had tools like Core Sets or something, it would definitely be helpful. Very helpful." [FG1_dietitian_2y experience]

The challenging endeavor to find a balance between completeness and clarity, was mentioned as an obstacle. (Barrier).

\section{CFIR domain outer setting}

Needs \& resources of those served by the organization

The extent to which the needs of those served by an organization (e.g., patients) are accurately known and prioritized by the organization [38,63]. No patient participated in any of the focus group, however, advantages for patients were addressed in all groups, for example the increased involvement of patients in the therapeutic process, the possibility to receive a more individualized therapy and continuity of care, as well as a better understanding of the findings and therapeutic goals by patients. (Facilitator)

"[...] also involving the person concerned. It's also a win for him, if he really has a clear dietetics diagnosis [...]." [FG1_dietitian_11y experience]

Using the ICF explicit for a single professional group (e.g. for dietitians) was seen as problem for patients and should be carefully considered. (Barrier)

"[...] if you want to use the ICF idea to break up [the deficit orientation] and focus on the patient rather than the profession, [...], I think it's very problematic, 
to introduce profession-specific things. [...] I do not object using it, just be aware that you are not losing, in a way, the basic goals of the whole, namely a stronger focus on participation, and on the activities." [FG3_physician_30y experience]

\section{Peer pressure}

Mimetic or competitive pressure to implement an innovation $[38,63]$. The fact that in the future it will be required to justify dietetic interventions against hospital association or social insurance institutions was an issue that was discussed as facilitator. (Facilitator).

As a great barrier in terms of difficulties in implementing the ICF the prevailing deficit-oriented health care was emphasized from one participant of a multidisciplinary group. (Barrier)

"[...] so we are extremely deficit-oriented and have been drilled in our training always deficit-oriented. And I think that this deficit-orientation is probably also the biggest barrier to coming to a simple language [like the ICF].”[FG4_physician_31y experience]

\section{External Policy \& Incentives}

This construct includes e.g. external strategies to spread innovations including policy and regulations, as well as public or benchmark reporting [38, 63]. Participants, especially in the program directors focus group, were convinced that it requires external policy and best practice examples to implement a standardized terminology. (Facilitator)

"[...] that in some cases best practice examples would be needed." [FG1_dietitian_2y experience]; "Maybe some way will then go through the Ministry, with the Quality Assurance Department [...].”

[FG2_director_30y experience]

\section{CFIR domain inner setting}

\section{Networks \& Communications}

The nature and quality of formal and informal communications within an organization $[38,63]$. In both multidisciplinary focus groups the importance of communications between all health professionals was discussed and practical examples were given on how communication within the interdisciplinary team in the inner setting of the institution could work. (Facilitator)

"So, we have an IT-technical network, where all professional groups see, if you [to the speech therapist] change something." [FG3_dietitian_18y experience]
One expert mentioned that using the ICF explicit for a single professional group is a great barrier not only for patients as described above but also for inter-professional communication. (Barrier)

\section{"[...] If that is not the standardized language of the} house at the same time. If the chef does not know what that is. If the nurse does not know exactly what it is. [...] the problem of a profession-specific language is that it immediately starts to become problematic if it is not permeable to other professions. [...]."

[FG3_physician_30y experience]

\section{Implementation climate (four sub-constructs were discussed)}

The capacity for change, shared receptivity of involved individuals to an innovation, and the extent to which use of that innovation will be supported within the organization $[38,63]$. It was emphasized that a successful implementation had to be supported from the management and leadership of the institutions. (Facilitator)

"But I now believe that it is the pressure in the houses that is needed, [...] that is, the pressure from above." [FG2_director_26y experience]

ICF-Dietetics fits in the dietetics care process, which was seen as advantage. The dietetic diagnosis finding process and the possibility for using ICF-based assessment instruments were positively mentioned. (Facilitator).

Rewards were discussed to be a facilitator while lacking rewards were seen as barrier. (Facilitator and Barrier).

One expert mentioned, the turning away from current dietetic assessments toward an assessment according the ICF components under the terms of the ICF model as a main barrier for a successful implementation. (Barrier)

"And if you say, okay, because of the classification you have to change the grammar [current assessment practice], that's a huge barrier. Nobody will want to go there.”[FG4_physician_31y experience]

\section{Readiness for implementation (two sub-constructs were discussed)}

Tangible and immediate indicators of organizational commitment to its decision to implement an innovation $[38,63]$. Participants mentioned that managers and the leadership of an institution had to embrace the implementation of the ICF-Dietetics in order to achieve successful implementation. (Facilitator) 
"[...] that has to be supported in the house, also by their structures. [...] I believe that this must be anchored in the quality management of a house, so that it then also will be integrated in the documentation systems." [FG2_director_26y experience]

A lack of involvement and commitment by the leadership was seen as a barrier to successful implementation. In that context, the financing of the implementation, additional time and personal resource were addressed as risks for the implementation. (Barrier)

"The institutions do not want that, because then their own staff needs even more documentation time."

[FG3_physician_30y experience]

\section{CFIR domain characteristics of individuals Knowledge \& Beliefs about the innovation}

Individuals' attitudes toward and value placed on the innovation, as well as familiarity with facts, truths, and principles related to the innovation $[38,63]$. The fact that was often mentioned was the importance of persuasion, especially, to convey the advantages of implementing the ICF-Dietetics within a multiprofessional approach, of the usability of the concept and that some criteria were already met by the current dietetic work. (Facilitator)

"[...] Yet, I believe that one would have to do a lot of persuading and also the advantages for the individual dietitian also should be worked out, so that this will be widely accepted." [FG1_dietitian_2y experience]; "That means, if you want to make it attractive for dietitians, then it is necessary that you really convey this concept and then convey the usability of the concept."

[FG4_physician_31y experience]

\section{Other personal attributes}

Other personal traits such as tolerance of ambiguity and motivation [38, 63]. The risk of stakeholders refusing the implementation of the ICF-Dietetics, because it is something new, was seen as an obstacle. (Barrier)

"But of course, it's a change and that will certainly be provoking resistance at the beginning [...], as with all new stuff." [FG1_dietitian_11y experience]

\section{CFIR domain process of implementation Planning}

A construct about scheme or method for implementing an innovation $[38,63]$. The majority of the participants considered a stepwise implementation process (bottomup) to be preferable. (Facilitator)

"Yes, so I join in too. I also think it's easier to take small steps." [FG3_nurse_4y experience]; "Serve the concept in healthy, tasty titbits." [FG4_linguist_16y experience]

Although some advantages for a top-down implementation were pointed out, more disadvantages were seen. (Barrier)

"A top-down process [...] certainly has its advantages, but the big disadvantage is that you have to realize it, as it were [...] it has to be succeeded."

[FG3_physician_30y experience]

\section{Engaging}

Involving appropriate individuals in the implementation and use of the innovation through a combined strategy of social marketing, education, and similar activities $[38,63]$. In this regard, the participants mentioned that it would be necessary to combine different strategies in the implementation, such as conducting trainings in the use of the ICFDietetics and the application concept for practicing dietitians and supervisors for interns on the one hand and for teachers of the universities on the other hand. The trainings have to be very practical and consistent among different providers. Furthermore, the concept has to be integrated in the curriculum of universities. (Facilitator)

"I think it also needs very specific training to be able to really apply that. It should also be integrated in the curriculum, in the universities, that it needs a special focus to learn gradually." [FG2_director_40y experience]

\section{Opinion leaders}

Individuals in an organization that have formal or informal influence on the attitudes and beliefs of their colleagues with respect to implementing the innovation $[38,63]$.

In a multidisciplinary group the advantage of an opinion leader was addressed. (Facilitator)

"And it really needs someone in a house who says: well, we'll do that now [...]. And then it takes a team that moves along, but it needs someone [...] as driving force." [FG4_linguist_16y experience]

\section{Linked interventions, theories and responsibilities}

The theory-based approach for linking focus group data and interventions was found to be valid by the subsequent 
applied group process. Results in terms of linked interventions, the underlying theories and the responsibilities in terms of responsible stakeholders according to intervention objectives and its context requirements is shown in Table 4. The interventions were allocated to five main responsible stakeholders (beside the engagement of institution leadership), namely the Association of Dietitians, the developer of the ICF-Dietetics application concept, potential implementation leaders, the program directors of universities of applied sciences and clinical dietitians as key stakeholders.

\section{The logic model for the ICF-dietetics implementation}

The logic model, shown in Fig. 3, summarizes the interventions with respect to its responsibilities. The implementation criteria were assigned to six implementation objectives with the responsibility of intervention leaders and dietitians, respectively: (1) provide information for other professional groups, (2) provide training on the coding with the ICF-Dietetics to change group processes, (3) integrate the ICF-Dietetics in electronic health information system and into all forms of documentation, (4) apply the ICFDietetics for goal setting and evaluation stepwise to all consultations, (5) establish a learning environment in terms of skills training and feedback on performance by an opinion leader or professional peers, as well as (6) defining individual goal for change. In addition, the implementation criteria were mapped to six context requirements at the following three levels of responsibilities: (1) developer of the ICF-Dietetics application concept (researcher and first author of this study), (2) the Association of Dietitians and directors of universities and (3) institution leadership.

\section{Discussion}

This study explored the clinical practicability and acceptability of the ICF-Dietetics along with barriers and facilitators to its nationwide implementation. The study was conducted prior to the implementation focusing on facilitators and barriers of a future implementation, since literature has shown that tailored implementation strategies increases the likelihood of successful dissemination and implementation [42, 47, 51, 72]. Merging our results, we established a logic model for the nationwide implementation of the ICF-Dietetics.

In general, the participants of the pretest agreed that the ICF-Dietetics would be useful and acceptable for clinical practice. Compared to the previous study of mapping clinical care report concepts to the ICFDietetics [10], the pretest showed that numerically more ICF-Dietetics categories (especially in the ICF component activities and participation as well as environmental factors) were applied (248 compared to 153 , respectively) in fewer documentations (55 compared to 100, respectively). This could be related to the fact that the dietitians were trained in the use of the ICF-Dietetics in the pretest study. As it was emphasized by participants of the pretest, the use of the ICF-Dietetics with its underlying biopsychosocial model helps to gain additional information that otherwise has been missed. We concluded that the ICF-Dietetics widens the perspective of dietitians. Furthermore, the pretest confirms all but one of the most frequently assigned ICF-Dietetics categories as described in the previous study [10] and added 22 more second level ICF-Dietetics categories to the list of ICFDietetics categories important for nutrition and dietetics that has been revealed by previous studies $[10,11]$. Thus, the final list consists of 160 second level ICF-Dietetics categories out of exactly 2402 ICF-Dietetics categories and 422 second level categories, respectively. This list of ICF-Dietetics categories could be used as basis for developing so called ICF-Dietetics Core Sets, which are purpose tailored short lists of ICF categories relevant for patients with a certain health condition [10].

Furthermore, participants of the pretest assumed the educational program to be sufficient enough for this pretest aiming at documenting the most important ICFDietetics categories for setting intervention goals based on the assessment and the dietetics diagnosis. However, considering $6 \mathrm{~h}$ of training might not be enough for an accurate and comprehensive use of a new standardized terminology for clinical dietetic care. They need more concrete examples to practice the application with feedback from others. Therefore, for a nationwide implementation of the ICF-Dietetics, more practice-related workshops have to be provided preferably before the implementation is rolled out. Moreover, the application was perceived in several parts as difficult. On the one hand, this was due to the fact that a new concept had to be applied, on the other hand, that the application concept developed for this project still needed to be improved. This is in line with literature regarding effective implementation of change in patients' care, e.g. change in clinical care practice is optimally achieved using welldesigned intervention [47] and presentation that is perceived as easily understandable by the professionals who would be affected by the planned change [38].

As main barrier, the complexity of the ICF-Dietetics was discussed in the focus groups. In this regard, the high number of about 2400 categories and the consequences of this, namely difficulties in assigning the appropriate one, has to be mentioned. This finding was confirmed by an earlier ICF implementation study in Germany [73]. However, the issue of complexity was also reported in implementing the NCP/NCPT [20]. Nevertheless, this barrier needs to be carefully targeted during the implementation. Otherwise, comparability would be substantially affected hence some categories were maybe more easily identified than others and the assignment 
Table 4 Results in terms of linked interventions, underlying theories and responsibilities based on implementation criteria according to CFIR domains/constructs

\begin{tabular}{|c|c|c|c|c|c|}
\hline CFIR Domain & CFIR Construct & $\begin{array}{l}\text { Implementation strategy criteria (points to } \\
\text { consider based on focus groups) }\end{array}$ & $\begin{array}{l}\text { Intervention (based on focus } \\
\text { groups and literature }[39,40 \text {, } \\
43,44,60-62] \text { ) }\end{array}$ & $\begin{array}{l}\text { Underlying } \\
\text { theory [27, 39, } \\
40]\end{array}$ & Responsibility \\
\hline \multirow[t]{16}{*}{$\begin{array}{l}\text { Intervention } \\
\text { characteristics }\end{array}$} & $\begin{array}{l}\text { Evidence } \\
\text { Strength \& } \\
\text { Quality }\end{array}$ & $\begin{array}{l}\text { Starting implementation with pilot } \\
\text { institutions. } \\
\text { Adducing ICF-Dietetics field studies and } \\
\text { other examples (e.g. nursing language). }\end{array}$ & Conduct a Pilot study & & $\begin{array}{l}\text { Research } \\
\text { Institution }\end{array}$ \\
\hline & $\begin{array}{l}\text { Relative } \\
\text { Advantage }\end{array}$ & Conveying the benefits of ICF-Dietetics. & $\begin{array}{l}\text { Provide information: on the } \\
\text { ICF-Dietetics its advantages } \\
\text { and disadvantages adapted to } \\
\text { different learning styles }\end{array}$ & $\begin{array}{l}\text { Cognitive theory } \\
\text { on learning }\end{array}$ & $\begin{array}{l}\text { Association of } \\
\text { Dietitians }\end{array}$ \\
\hline & (disadvantage) & $\begin{array}{l}\text { Considering the drawbacks of using the } \\
\text { ICF in form of a professional-specific } \\
\text { terminology. } \\
\text { Avoiding over-categorizing. }\end{array}$ & $\begin{array}{l}\text { Provide information for other } \\
\text { professional groups } \\
\text { Refine application concept to } \\
\text { improve attractiveness }\end{array}$ & $\begin{array}{l}\text { Theory on } \\
\text { organizational } \\
\text { learning, } \\
\text { Theory on } \\
\text { learning }\end{array}$ & $\begin{array}{l}\text { Implementation } \\
\text { leader }^{1} \\
\text { Developer of } \\
\text { the concept }{ }^{2}\end{array}$ \\
\hline & $\begin{array}{l}\text { (advantage and } \\
\text { disadvantage) }\end{array}$ & $\begin{array}{l}\text { To consider if the ICF model should be } \\
\text { introduced in education and practice. }\end{array}$ & $\begin{array}{l}\text { Refine application concept to } \\
\text { improve attractiveness }\end{array}$ & $\begin{array}{l}\text { Theory on } \\
\text { learning }\end{array}$ & $\begin{array}{l}\text { Developer of } \\
\text { the concept }\end{array}$ \\
\hline & Adaptability & $\begin{array}{l}\text { The application concept and the ICF- } \\
\text { Dietetics (granularity) have to be adaptable } \\
\text { to different settings and workflows in } \\
\text { professional practice. } \\
\text { In principle, the ICF / ICF-Dietetics offers } \\
\text { this possibility. }\end{array}$ & $\begin{array}{l}\text { Provide information: on the } \\
\text { possibility for adaptability to } \\
\text { different settings adapted to } \\
\text { different learning styles } \\
\text { Enable self-regulation to adapt } \\
\text { application to individual } \\
\text { needs }\end{array}$ & $\begin{array}{l}\text { Cognitive theory } \\
\text { on learning } \\
\text { Behavior, } \\
\text { observational } \\
\text { learning }\end{array}$ & $\begin{array}{l}\text { Association of } \\
\text { Dietitians } \\
\text { Developer of } \\
\text { the concept }\end{array}$ \\
\hline & Trialability & $\begin{array}{l}\text { Providing examples for practice purposes } \\
\text { before implementation. }\end{array}$ & $\begin{array}{l}\text { Start with practical-related } \\
\text { interactive workshops before } \\
\text { implementation }\end{array}$ & $\begin{array}{l}\text { Social cognitive } \\
\text { theory }\end{array}$ & $\begin{array}{l}\text { Association of } \\
\text { Dietitians }\end{array}$ \\
\hline & Complexity & $\begin{array}{l}\text { Being aware of barriers of complexity. } \\
\text { It takes extensive experience regarding the } \\
\text { assignment to appropriate ICF-Dietetics } \\
\text { categories, the use of qualifiers, as well as } \\
\text { the assignment to environmental factors } \\
\text { and personal factors. }\end{array}$ & $\begin{array}{l}\text { Start with practical-related } \\
\text { interactive workshops before } \\
\text { implementation } \\
\text { Provide training to change } \\
\text { group processes }\end{array}$ & $\begin{array}{l}\text { Social cognitive } \\
\text { theory } \\
\text { Theory on team } \\
\text { effectiveness, } \\
\text { group decisions }\end{array}$ & $\begin{array}{l}\text { Association of } \\
\text { Dietitians (ICF } \\
\text { trainers) } \\
\text { Implementation } \\
\text { leader }\end{array}$ \\
\hline & & & $\begin{array}{l}\text { Provide skills training and } \\
\text { feedback on performance }\end{array}$ & $\begin{array}{l}\text { Cognitive theory } \\
\text { on learning }\end{array}$ & $\begin{array}{l}\text { Implementation } \\
\text { leader }\end{array}$ \\
\hline & & & $\begin{array}{l}\text { Enable self-regulation to adapt } \\
\text { application to individual } \\
\text { needs }\end{array}$ & $\begin{array}{l}\text { Behavior, } \\
\text { observational } \\
\text { learning }\end{array}$ & $\begin{array}{l}\text { Developer of } \\
\text { the concept }\end{array}$ \\
\hline & & Putting codes in the background. & $\begin{array}{l}\text { Refine application concept to } \\
\text { improve attractiveness }\end{array}$ & $\begin{array}{l}\text { Theory on } \\
\text { learning }\end{array}$ & $\begin{array}{l}\text { Developer of } \\
\text { the concept }\end{array}$ \\
\hline & & $\begin{array}{l}\text { Recognizing the large number of ICF- } \\
\text { Dietetics categories as a major barrier. } \\
\text { Being aware of the need to develop a } \\
\text { nutrition and dietetics-related Core Set. }\end{array}$ & $\begin{array}{l}\text { Refine application concept to } \\
\text { improve attractiveness: } \\
\text { Develop a nutrition and } \\
\text { dietetics-related Core Set }\end{array}$ & $\begin{array}{l}\text { Theory on } \\
\text { learning }\end{array}$ & $\begin{array}{l}\text { Developer of } \\
\text { the concept or } \\
\text { Researcher }\end{array}$ \\
\hline & & Being aware of the barrier of initial effort. & $\begin{array}{l}\text { Define individual goals for } \\
\text { change }\end{array}$ & $\begin{array}{l}\text { Motivational } \\
\text { theories }\end{array}$ & $\begin{array}{l}\text { Implementation } \\
\text { leader }\end{array}$ \\
\hline & & $\begin{array}{l}\text { Taking into account and communicate the } \\
\text { need of additional time especially, at the } \\
\text { beginning. }\end{array}$ & $\begin{array}{l}\text { Provide training to change } \\
\text { group processes }\end{array}$ & $\begin{array}{l}\text { Theory on team } \\
\text { effectiveness, } \\
\text { group decisions }\end{array}$ & $\begin{array}{l}\text { Implementation } \\
\text { leader }\end{array}$ \\
\hline & & $\begin{array}{l}\text { Perceived incompleteness of the ICF- } \\
\text { Dietetics categories may come through } \\
\text { lack of practice and experience in the use } \\
\text { of the new language. }\end{array}$ & $\begin{array}{l}\text { Involve opinion leaders or } \\
\text { professional peers } \\
\text { (educational outreach) }\end{array}$ & $\begin{array}{l}\text { Theories of } \\
\text { planned } \\
\text { behavior and } \\
\text { social } \\
\text { comparison }\end{array}$ & $\begin{array}{l}\text { Implementation } \\
\text { leader }\end{array}$ \\
\hline & $\begin{array}{l}\text { Design Quality \& } \\
\text { Packaging }\end{array}$ & $\begin{array}{l}\text { There is a need for an intelligent search } \\
\text { function, and the integration of the ICF- } \\
\text { Dietetics in electronic health record } \\
\text { systems. }\end{array}$ & $\begin{array}{l}\text { Incorporate the ICF-Dietetics } \\
\text { into existing information sys- } \\
\text { tems for coding purposes }\end{array}$ & $\begin{array}{l}\text { Theory on } \\
\text { organizational } \\
\text { learning }\end{array}$ & $\begin{array}{l}\text { Implementation } \\
\text { leader or } \\
\text { institution } \\
\text { leadership }\end{array}$ \\
\hline & & The application concept has to be well & Refine application concept to & Theory on & Developer of \\
\hline
\end{tabular}


Table 4 Results in terms of linked interventions, underlying theories and responsibilities based on implementation criteria according to CFIR domains/constructs (Continued)

\begin{tabular}{|c|c|c|c|c|c|}
\hline CFIR Domain & CFIR Construct & $\begin{array}{l}\text { Implementation strategy criteria (points to } \\
\text { consider based on focus groups) }\end{array}$ & $\begin{array}{l}\text { Intervention (based on focus } \\
\text { groups and literature }[39,40 \text {, } \\
43,44,60-62] \text { ) }\end{array}$ & $\begin{array}{l}\text { Underlying } \\
\text { theory [27, 39, } \\
40]\end{array}$ & Responsibility \\
\hline & & $\begin{array}{l}\text { designed and clear. Clarifying questions, } \\
\text { such as; what should be documented? } \\
\text { What should be done with the } \\
\text { documentation? }\end{array}$ & improve attractiveness & learning & the concept \\
\hline & & $\begin{array}{l}\text { Beginning with a small Core Set, that } \\
\text { should be extensible. }\end{array}$ & $\begin{array}{l}\text { Refine application concept to } \\
\text { improve attractiveness: } \\
\text { develop a nutrition and } \\
\text { dietetics-related Core Set }\end{array}$ & $\begin{array}{l}\text { Theory on } \\
\text { learning }\end{array}$ & $\begin{array}{l}\text { Developer of } \\
\text { the concept }\end{array}$ \\
\hline & & Beginning with a simplified application. & $\begin{array}{l}\text { Refine application concept to } \\
\text { improve attractiveness }\end{array}$ & $\begin{array}{l}\text { Theory on } \\
\text { learning }\end{array}$ & $\begin{array}{l}\text { Developer of } \\
\text { the concept }\end{array}$ \\
\hline & & There is a need for a table of contents. & $\begin{array}{l}\text { Refine application concept to } \\
\text { improve attractiveness }\end{array}$ & $\begin{array}{l}\text { Theory on } \\
\text { learning }\end{array}$ & $\begin{array}{l}\text { Developer of } \\
\text { the concept }\end{array}$ \\
\hline & & $\begin{array}{l}\text { There is a need for a revision of the ICF- } \\
\text { Dietetics (in cooperation with the proprietors } \\
\text { of the original ICF-Dietetics). }\end{array}$ & $\begin{array}{l}\text { Refine application concept to } \\
\text { improve attractiveness: Revise } \\
\text { the ICF-Dietetics }\end{array}$ & $\begin{array}{l}\text { Theory on } \\
\text { learning }\end{array}$ & $\begin{array}{l}\text { Developer of } \\
\text { the concept }\end{array}$ \\
\hline & & $\begin{array}{l}\text { There is a need for a balance between } \\
\text { completeness and not confusing. }\end{array}$ & $\begin{array}{l}\text { Refine application concept to } \\
\text { improve attractiveness: Revise } \\
\text { the ICF-Dietetics }\end{array}$ & $\begin{array}{l}\text { Theory on } \\
\text { learning }\end{array}$ & $\begin{array}{l}\text { Developer of } \\
\text { the concept }\end{array}$ \\
\hline \multirow[t]{6}{*}{ Outer setting } & $\begin{array}{l}\text { Needs \& } \\
\text { Resources of } \\
\text { Those Served by } \\
\text { the Organization }\end{array}$ & $\begin{array}{l}\text { Focusing on patient orientation and } \\
\text { patient goals and continuing of care. } \\
\text { Recognizing that the focus only on } \\
\text { interventions goals, that has set by health } \\
\text { professionals could be a great barrier in } \\
\text { terms of patient-centered care. }\end{array}$ & $\begin{array}{l}\text { Take care of patient focused } \\
\text { goals and satisfaction }\end{array}$ & $\begin{array}{l}\text { Theory on } \\
\text { quality } \\
\text { management }\end{array}$ & Dietitians \\
\hline & Peer Pressure & $\begin{array}{l}\text { Conveying the awareness of the necessity } \\
\text { to ensure evidence in the future. }\end{array}$ & $\begin{array}{l}\text { Provide general information: } \\
\text { to ensure evidence }\end{array}$ & $\begin{array}{l}\text { Cognitive theory } \\
\text { on learning }\end{array}$ & $\begin{array}{l}\text { Association of } \\
\text { Dietitians }\end{array}$ \\
\hline & $\begin{array}{l}\text { External Policy \& } \\
\text { Incentives }\end{array}$ & $\begin{array}{l}\text { The implementation of the ICF-Dietetics } \\
\text { nation-wide should be supported by } \\
\text { politics and legal regulation. }\end{array}$ & $\begin{array}{l}\text { Influence decision makers, } \\
\text { build political support }\end{array}$ & $\begin{array}{l}\text { Theory on } \\
\text { agenda building }\end{array}$ & $\begin{array}{l}\text { Association of } \\
\text { Dietitians }\end{array}$ \\
\hline & & $\begin{array}{l}\text { Presentation of the concept at congresses } \\
\text { and other health care events. }\end{array}$ & $\begin{array}{l}\text { Influence decision makers, } \\
\text { build stakeholder support }\end{array}$ & $\begin{array}{l}\text { Theory on } \\
\text { agenda building }\end{array}$ & $\begin{array}{l}\text { Association of } \\
\text { Dietitians }\end{array}$ \\
\hline & & $\begin{array}{l}\text { The recently started realization of Primary } \\
\text { Health Care Centers could be facilitate the } \\
\text { implementation of a multidisciplinary } \\
\text { applicable terminology. }\end{array}$ & $\begin{array}{l}\text { Influence decision makers, } \\
\text { build public support }\end{array}$ & $\begin{array}{l}\text { Theory on } \\
\text { agenda building }\end{array}$ & $\begin{array}{l}\text { Association of } \\
\text { Dietitians }\end{array}$ \\
\hline & & Publishing best practice examples. & $\begin{array}{l}\text { Provide information of best } \\
\text { practice examples }\end{array}$ & $\begin{array}{l}\text { Cognitive theory } \\
\text { on learning }\end{array}$ & $\begin{array}{l}\text { Association of } \\
\text { Dietitians }\end{array}$ \\
\hline \multirow[t]{4}{*}{ Inner setting } & $\begin{array}{l}\text { Networks \& } \\
\text { Communications }\end{array}$ & $\begin{array}{l}\text { Integrating and inform other health care } \\
\text { professional and aiming a common } \\
\text { solution. }\end{array}$ & $\begin{array}{l}\text { Make better use of } \\
\text { information technology } \\
\text { Provide information for other } \\
\text { professional groups }\end{array}$ & $\begin{array}{l}\text { Theory on } \\
\text { organizational } \\
\text { learning Theory } \\
\text { on integrated } \\
\text { care }\end{array}$ & $\begin{array}{l}\text { Implementation } \\
\text { leader or } \\
\text { institution } \\
\text { leadership }\end{array}$ \\
\hline & $\begin{array}{l}\text { Tension for } \\
\text { Change }\end{array}$ & $\begin{array}{l}\text { Necessity for implementation have to } \\
\text { come from leadership of institutions. }\end{array}$ & $\begin{array}{l}\text { Provide specific information } \\
\text { on the advantages of the ICF- } \\
\text { Dietetics for managers and } \\
\text { the leadership of the } \\
\text { institution }\end{array}$ & $\begin{array}{l}\text { Theories on } \\
\text { persuasion and } \\
\text { leadership }\end{array}$ & $\begin{array}{l}\text { Implementation } \\
\text { leader }\end{array}$ \\
\hline & & $\begin{array}{l}\text { Tension for change has to be seen and } \\
\text { build up within the professional group. }\end{array}$ & $\begin{array}{l}\text { Implement continuous } \\
\text { improvement activities }\end{array}$ & $\begin{array}{l}\text { Theories on } \\
\text { quality } \\
\text { management }\end{array}$ & $\begin{array}{l}\text { Implementation } \\
\text { leader or } \\
\text { institution } \\
\text { leadership }\end{array}$ \\
\hline & Compatibility & $\begin{array}{l}\text { ICF-Dietetics needs to be adapted to the } \\
\text { dietetic care process, not the other way } \\
\text { around. } \\
\text { The ICF is not an assessment, but for }\end{array}$ & $\begin{array}{l}\text { Implement continuous } \\
\text { improvement activities }\end{array}$ & $\begin{array}{l}\text { Theories on } \\
\text { quality } \\
\text { management }\end{array}$ & $\begin{array}{l}\text { Implementation } \\
\text { leader or } \\
\text { institution } \\
\text { leadership }\end{array}$ \\
\hline
\end{tabular}


Table 4 Results in terms of linked interventions, underlying theories and responsibilities based on implementation criteria according to CFIR domains/constructs (Continued)

\begin{tabular}{|c|c|c|c|c|c|}
\hline CFIR Domain & CFIR Construct & $\begin{array}{l}\text { Implementation strategy criteria (points to } \\
\text { consider based on focus groups) }\end{array}$ & $\begin{array}{l}\text { Intervention (based on focus } \\
\text { groups and literature }[39,40 \text {, } \\
43,44,60-62] \text { ) }\end{array}$ & $\begin{array}{l}\text { Underlying } \\
\text { theory [27, 39, } \\
40]\end{array}$ & Responsibility \\
\hline & & & $\begin{array}{l}\text { Create teams/collaborative for } \\
\text { improvement }\end{array}$ & $\begin{array}{l}\text { Theories on } \\
\text { quality } \\
\text { management }\end{array}$ & $\begin{array}{l}\text { Implementation } \\
\text { leader or } \\
\text { institution } \\
\text { leadership }\end{array}$ \\
\hline & & & $\begin{array}{l}\text { Recruit and train leaders to } \\
\text { integrate or establish a } \\
\text { continuous improvement } \\
\text { program in dietetics care }\end{array}$ & $\begin{array}{l}\text { Theories on } \\
\text { quality } \\
\text { management }\end{array}$ & $\begin{array}{l}\text { Implementation } \\
\text { leader or } \\
\text { institution } \\
\text { leadership }\end{array}$ \\
\hline & & & $\begin{array}{l}\text { Enable self-regulation to adapt } \\
\text { application to individual } \\
\text { needs }\end{array}$ & $\begin{array}{l}\text { Behavior, } \\
\text { observational } \\
\text { learning }\end{array}$ & $\begin{array}{l}\text { Developer of } \\
\text { the concept }\end{array}$ \\
\hline & Relative Priority & $\begin{array}{l}\text { Conducting needs assessment before } \\
\text { implementation, e.g., about the perceived } \\
\text { importance of implementing a } \\
\text { standardized terminology in dietetics. }\end{array}$ & $\begin{array}{l}\text { Not necessary: evaluations } \\
\text { have already been conducted }\end{array}$ & & \\
\hline & $\begin{array}{l}\text { Organizational } \\
\text { Incentives \& } \\
\text { Rewards }\end{array}$ & $\begin{array}{l}\text { There should be a defined compensation } \\
\text { of the additional required time and the } \\
\text { recognition from the leadership of the } \\
\text { institutions. }\end{array}$ & $\begin{array}{l}\text { Define compensation of the } \\
\text { additional required time and } \\
\text { the recognition from the } \\
\text { leadership of the institutions }\end{array}$ & $\begin{array}{l}\text { Reimbursement } \\
\text { theories }\end{array}$ & $\begin{array}{l}\text { Implementation } \\
\text { leader or } \\
\text { institution } \\
\text { leadership }\end{array}$ \\
\hline & $\begin{array}{l}\text { Leadership } \\
\text { Engagement }\end{array}$ & $\begin{array}{l}\text { Management and leadership of institutions } \\
\text { (e.g. the quality assurance departments) } \\
\text { have to take responsibility for the } \\
\text { implementation. }\end{array}$ & $\begin{array}{l}\text { Provide specific information } \\
\text { on the advantages of the ICF- } \\
\text { Dietetics for managers and } \\
\text { the leadership of the } \\
\text { institution }\end{array}$ & $\begin{array}{l}\text { Theories on } \\
\text { persuasion and } \\
\text { leadership }\end{array}$ & $\begin{array}{l}\text { Implementation } \\
\text { leader }\end{array}$ \\
\hline & $\begin{array}{l}\text { Available } \\
\text { Resources }\end{array}$ & $\begin{array}{l}\text { Resources, especially time and/or } \\
\text { additional human resources, have to be } \\
\text { clarified in advance. }\end{array}$ & $\begin{array}{l}\text { Provide information about } \\
\text { additional resources and } \\
\text { clarify them in advance }\end{array}$ & $\begin{array}{l}\text { Theories of } \\
\text { Leadership }\end{array}$ & $\begin{array}{l}\text { Implementation } \\
\text { leader }\end{array}$ \\
\hline \multirow[t]{3}{*}{$\begin{array}{l}\text { Characteristics } \\
\text { of individual }\end{array}$} & \multirow[t]{2}{*}{$\begin{array}{l}\text { Knowledge \& } \\
\text { Beliefs about the } \\
\text { Innovation }\end{array}$} & $\begin{array}{l}\text { Conveying clear usability of the application } \\
\text { concept and the ICF-Dietetics, e.g. how it } \\
\text { works and which steps and ICF-Dietetics } \\
\text { categories should be documented. }\end{array}$ & $\begin{array}{l}\text { Provide general information } \\
\text { Involve opinion leaders or } \\
\text { professional peers } \\
\text { (educational outreach) }\end{array}$ & $\begin{array}{l}\text { Cognitive theory } \\
\text { on learning } \\
\text { Motivational } \\
\text { theories }\end{array}$ & $\begin{array}{l}\text { Association of } \\
\text { Dietitians } \\
\text { Implementation } \\
\text { leader }\end{array}$ \\
\hline & & $\begin{array}{l}\text { Conveying the usability of the ICF-Dietetics } \\
\text { within a multiprofessional approach, and } \\
\text { conveying that not everything is new, but } \\
\text { has already been applied in dietetic } \\
\text { practice. }\end{array}$ & $\begin{array}{l}\text { Provide general information } \\
\text { Involve opinion leaders or } \\
\text { professional peers } \\
\text { (educational outreach) }\end{array}$ & $\begin{array}{l}\text { Cognitive theory } \\
\text { on learning } \\
\text { Motivational } \\
\text { theories }\end{array}$ & $\begin{array}{l}\text { Association of } \\
\text { Dietitians } \\
\text { Implementation } \\
\text { leader }\end{array}$ \\
\hline & $\begin{array}{l}\text { Other Personal } \\
\text { Attributes }\end{array}$ & $\begin{array}{l}\text { Motivating dietitians in order to prevent } \\
\text { resistance, e.g. motivate them to }\end{array}$ & $\begin{array}{l}\text { Define individual goals for } \\
\text { change }\end{array}$ & $\begin{array}{l}\text { Motivational } \\
\text { theories }\end{array}$ & $\begin{array}{l}\text { Implementation } \\
\text { leader }\end{array}$ \\
\hline
\end{tabular}

Process of Planning Evaluate what is taught at universities implementation overcome the first needed effort for a higher aim. regarding standardized terminologies in general and about the ICF in particular.

Planning the implementation stepwise (e.g., firstly, standardizing the assessments and the dietetics diagnosis, then adopting intervention goals with pre-defined goal lists in terms of ICF-Dietetics categories).

Standardizing the dietetic care process that is taught in universities.

Further validation of the ICF-Dietetics should be done in the ongoing process.

Engaging
Offering of trainings and ICF workshops for practicing dietitians, supervisors for interns and teachers.
Not necessary: all program directors of universities participated in the focus groups

Apply intervention stepwise according to the "stage" of change

Standardize teaching plans of dietetics universities

Refine application concept to improve attractiveness: Revise the ICF-Dietetics

Start with practical-related interactive workshops before implementation
Stages-of-

Change Theories

Dietitians

Theory on learning

Theory on

learning

Social cognitive

theory

Theory of Total
Directors of universities

Dietitians and developer of the concept

Association of Dietitians Implementation 
Table 4 Results in terms of linked interventions, underlying theories and responsibilities based on implementation criteria according to CFIR domains/constructs (Continued)

\begin{tabular}{|c|c|c|c|c|c|}
\hline CFIR Domain & CFIR Construct & $\begin{array}{l}\text { Implementation strategy criteria (points to } \\
\text { consider based on focus groups) }\end{array}$ & $\begin{array}{l}\text { Intervention (based on focus } \\
\text { groups and literature [39, 40, } \\
43,44,60-62] \text { ) }\end{array}$ & $\begin{array}{l}\text { Underlying } \\
\text { theory [27, 39, } \\
40]\end{array}$ & Responsibility \\
\hline & & & Provide continuous trainings & $\begin{array}{l}\text { Quality } \\
\text { Management }\end{array}$ & leader \\
\hline & & $\begin{array}{l}\text { Developing practice-oriented standardized } \\
\text { training material. }\end{array}$ & $\begin{array}{l}\text { Provide printed educational } \\
\text { material, e.g. a manual of the } \\
\text { dietetics care process and the } \\
\text { use of the ICF-Dietetics }\end{array}$ & $\begin{array}{l}\text { Theory on } \\
\text { learning }\end{array}$ & $\begin{array}{l}\text { Association of } \\
\text { Dietitians }\end{array}$ \\
\hline & Opinion Leaders & $\begin{array}{l}\text { Institutions need a person as an opinion } \\
\text { leader. }\end{array}$ & $\begin{array}{l}\text { Involve opinion leaders or } \\
\text { professional peers } \\
\text { (educational outreach) }\end{array}$ & $\begin{array}{l}\text { Theories of } \\
\text { planned } \\
\text { behavior and } \\
\text { social } \\
\text { comparison }\end{array}$ & $\begin{array}{l}\text { Implementation } \\
\text { leader }\end{array}$ \\
\hline & $\begin{array}{l}\text { (Key } \\
\text { Stakeholders) }\end{array}$ & $\begin{array}{l}\text { Addressing different settings and work } \\
\text { experience of dietitians, such as, students, } \\
\text { freelancers and employees, those they just } \\
\text { finished their education and those who } \\
\text { have been in practice for many years. }\end{array}$ & $\begin{array}{l}\text { Provide information on the } \\
\text { ICF-Dietetics for adaptability } \\
\text { to different settings adapt to } \\
\text { different learning styles }\end{array}$ & $\begin{array}{l}\text { Cognitive theory } \\
\text { on learning }\end{array}$ & $\begin{array}{l}\text { Association of } \\
\text { Dietitians }\end{array}$ \\
\hline
\end{tabular}

\footnotetext{
${ }^{1}$ The implementation leader is someone who is the champion on each facility usually the leading dietitian

${ }^{2}$ The developer of the concept is the researcher who has develop the application concept to integrate the ICF-dietetics in the Austrian dietetic care process

${ }^{3}$ The construct key stakeholder is described in the CFIR codebook however not mentioned as separate CFIR construct by Damschroder et al. [38]
}

could depend on users. Advantages of a more stringent and logical re-definition of the ICF categories in general have also been reported by Heerkens et al. [74], such as reduction of ambiguity of concepts and improvement of ICF use efficacy that would lead to better semantic interoperability. Moreover, information, training and education of the professionals who are going to use the ICFDietetics, might be a possible strategy to overcome the complexity of difficulties regarding the number of categories and their assignment. Training was not only an important topic in our study, but also found to be a critical success factor in other studies [18, 20,73]. It has to be mentioned, not every education is effective in changing practice [47, 71]. For successful implementation strategy, interactive and continuous education, including discussion of evidence and feedback on performance

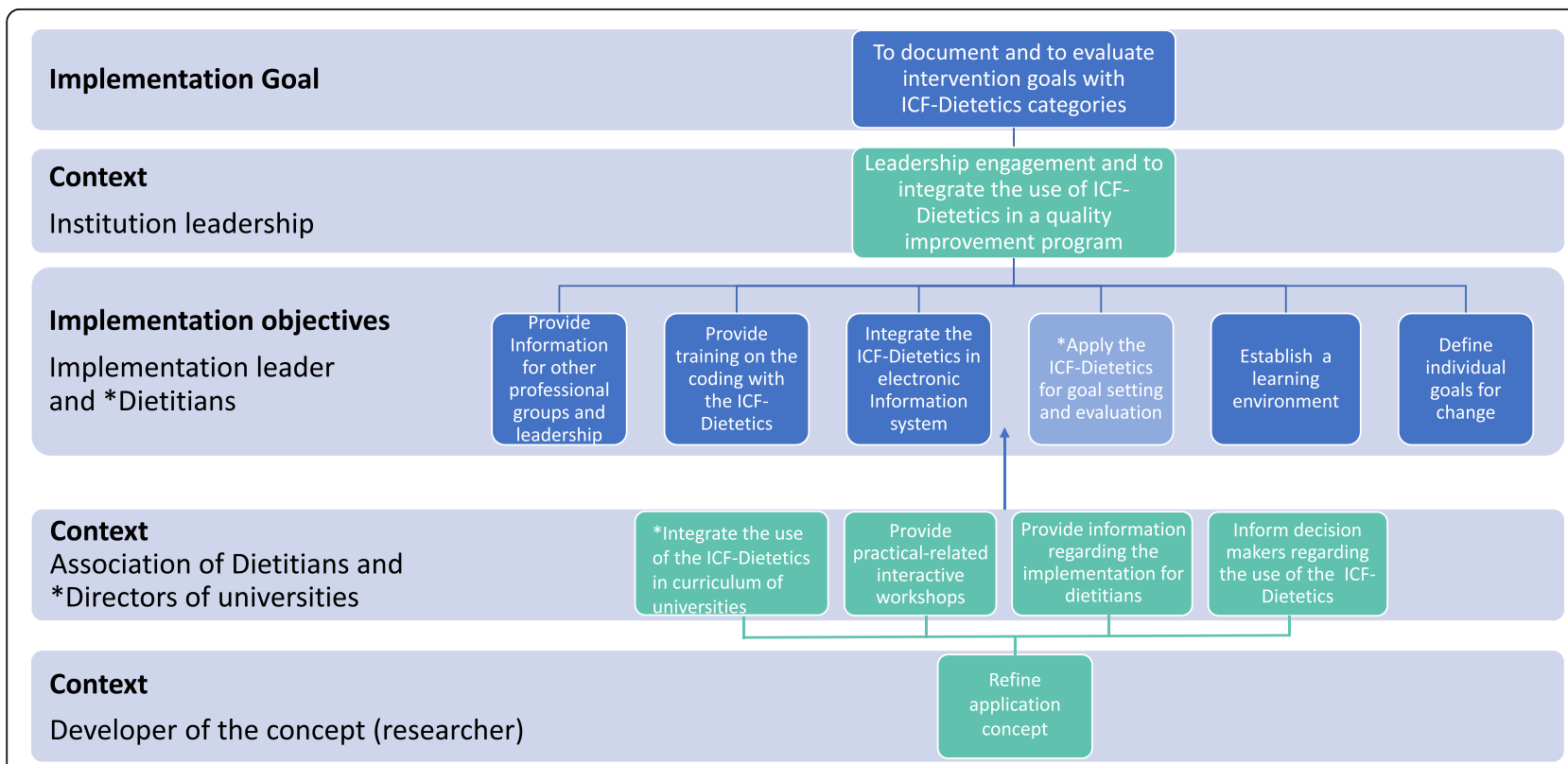

Fig. 3 Logic model for the ICF-Dietetics implementation. This logic model was developed by merging results of linked interventions according to its responsibilities which are shown in Table 4 
$[19,47,53]$ or educational outreach visits [52] are needed.

The web-based search function that had been provided for the pretest was seen as great advantage in usability. Additionally, a highly-recommended improvement before implementation in a larger scale, the integration of the ICF-Dietetics in electronic health record system was discussed as imperative, and confirmed by other studies [13, 75]. Rossi et al. [13], for instance, have shown in terms of implementation of the NCP and NCPT in a Single-Center Hemodialysis Unit, significant improvements in the efficiency of nutrition care and effectiveness related to patient outcomes of an electronic versus a manual paper-based nutrition care documentation system. Vreeman and Richoz [75] have pointed out that incorporating ICF and other internationally accepted standardized terminologies and aid tools into clinical information systems, assist the clinical decision-making thus advance clinical practice and research by enabling data sharing.

Regarding the implementation process the majority of focus group participants in our study emphasized that a stepwise (bottom-up) approach would be preferable compared to a top-down approach. For example, focus group participants mentioned, firstly, standardizing the assessment and the dietetics diagnosis step, secondly, adopting intervention goals with pre-defined goal lists in terms of ICF-Dietetics categories that can be evaluated. The major concern regarding the top-down approach discussed by one participant was the implementability nationwide. Taking all focus group discussions into consideration, a combined strategy would be necessary, namely, encouraging and empowering people to achieve change in their range of influence on the one side, providing central coordination of efforts from leadership of institution, politics and the association of dietitians on the other side. This approach is in line with Ham et al. [76], who have indicated, that the role of organizations at different levels needs to be addressed as part of an integrated and coherent quality improvement strategy. The important roles and interrelationships of leadership engagement and available resources have been discussed in the focus groups and shown in literature [45, 77], for instance, the leadership engagement can lead to provision of sufficient available resources in terms of dedicated time. Consequently, the leadership engagement and integration of the ICF-Dietetics in a quality improvement program will be crucial and a prerequisite for a successful nationwide implementation.

Moreover, results of the focus groups showed the importance of facilitating policy and external incentives as potential context factors for the implementation of a standardized terminology which is also confirmed in literature $[38,57,78]$. Therefore, lobbying with decision makers regarding the use of the ICF-Dietetics by the Association of Dietitians might be essential. While training or educational strategies typically target knowledge and skills, financial and policy strategies enhance fidelity and acceptance [57] and both play an important role when implementing a standardized terminology.

\section{Strengths and limitations}

Identified criteria (points to consider) in terms of barriers and facilitators could be linked to interventions and responsibilities applying a structured framework to inform a targeted nationwide implementation strategy. Using the codebook of the CFIR provided us with constructs and definitions for organizing qualitative data. The main benefits of this approach, such as to have an a priori templates, is that it accelerates the coding process and generates comparable results. The first coding and developing intervention-specific themes helped us to overcome the disadvantages of attending predefined constructs, namely, of missing important aspects. From our findings in terms of in-depth interviews, we conclude that focus groups were a suitable method to identify barriers and facilitators regarding the implementation of a standardized terminology. We found, that focus groups allowed the participants to discuss and question perspectives of colleagues, that, in turn raised some more important perspectives that could be investigated in addition, for example in terms of Core Set development and assessment instruments.

The pretest was necessary to evaluate the practicability of the application concept for integrating the ICFDietetics in clinical practice. The aims were foremost to validate the developed application concept and to inform the subsequent focus groups. Due to the wide range of application possibilities of the ICF-Dietetics and the about 2400 categories a standardized application concept is a requirement for standardized use of the ICFDietetics. Otherwise, as discussed above, comparability would be substantially affected.

A limitation of the pretest was that the results are restricted to one institution and to only four of 22 dietitians who applied the ICF-Dietetics in their clinical practice. Therefore, the results of the pretest are not generalizable for other settings. Moreover, these four dietitians who volunteered for participating in our study could have had in principle a more positive attitude towards implementing the ICF-Dietetics when compared to their colleagues. A generally positive attitude may be a facilitator in implementing the ICF-Dietetics in clinical practice in itself. No reason of not participating was asked, we assume as possible reasons time constraints and lack of interest. This could reflect the general interest and attitude of implementing a standardized terminology in clinical practice. To generate interest in a common new terminology, information and activities 
that lead towards a positive attitude would be essential in a successful implementation strategy. Individual goals for change as well as incentives may further help to motivate dietitians [36].

A further limitation is our sampling approach of selecting extreme cases which affects generalizability of focus group results. Choosing the four dietitians who took part in the pretest and multidisciplinary groups that are already applying the ICF might have caused a selection bias due to missing opinions of ICF-Dietetics opponents. However, we applied this method to get in-depth insight of a specific group of experts that were acquainted with advantages and disadvantages of the ICF usage in clinical practice for informing an implementation strategy.

\section{Conclusions}

The results of this study demonstrated that for a successful nationwide implementation of the ICF-Dietetics, several specific criteria concerning the ICF-Dietetics and the application concept should be addressed and specific interventions need to be applied by different stakeholders. These results set the foundation for developing a targeted implementation strategy to increase the success, reproducibility and comparability.

\section{Supplementary information}

Supplementary information accompanies this paper at https://doi.org/10. 1186/s12913-019-4600-5
Additional file 1. Documentation tools.
Additional file 2. Interview guide for focus groups.
Additional file 3. List of applied second-level ICF-Dietetics categories in respect of medical areas.
Additional file 4. Implementation criteria according to CFIR domains/ constructs and identified higher level-themes.

\section{Abbreviations \\ CFIR: Consolidated Framework of Implementation Research; DCP: Dietetic care process; ICF-Dietetics : International Classification of Functioning, Disability and Health for Dietetics; NCP: Nutrition care process; NCPT: Nutrition care process terminology}

\section{Acknowledgements}

We would like to thank all participants of the focus groups for interesting and informative discussions. Special thanks go to the dietitians who applied the ICF-Dietetics in their clinical practice. Finally, we would like to acknowledge FHProf. Daniela Wewerka-Kreimel, MBA and FH-Prof. Alexandra Kolm, MSc for their helpful feedback on the educational program.

\footnotetext{
Authors' contributions

All authors (GG, MC, KF, MC, TS) contributed substantially to the design and execution of this study and have read and approved the manuscript. GG and TS prepared the study protocol. TS supervised and advised GG with regard to the methodology. GG developed the application concept and the educational program, performed the data collection and analysis, wrote the first draft of the manuscript and prepared tables and figures supervised with substantial contribution of TS and MC; KF transcribed focus group data; MT was responsible for the pretest. All authors took part in the explorative group-based approach.
}

\section{Funding}

This study was partially funded by the Austrian Association of Dietitians, however, the Association had no involvement in the research or in the preparation of the article.

\section{Availability of data and materials}

Most of the data generated or analyzed during this study are included in this published article [and its supplementary information files]. The original transcripts and entire original framework analysis matrix (both in German language) are available from the corresponding author on reasonable request.

\section{Ethics approval and consent to participate}

The study was performed in accordance with the Declaration of Helsinki. However, it had been granted an exemption from requiring ethics approval by the Ethics Committee of the Medical University of Vienna. Ethical committee approval was not required, since only expert opinion and no patient data were analyzed. Importantly, only the documented ICF-Dietetics codes and categories by the dietitians were used for the pretest. The participation was voluntary. The dietitians who applied the ICF-Dietetics concept in clinical practice as well as all other participants of the focus groups were informed in detail about the study procedures and gave written and verbal informed consent. In addition, focus group data of experts was coded with a pseudonym.

\section{Consent for publication}

Not applicable.

\section{Competing interests}

The authors MC, KF and MT declares that they have no competing interests regarding this study; GG and TS reports grants from Austrian Dietetics Association, during the conduct of the study. However, the Association had no involvement in the research or in the preparation of the article.

\section{Author details}

${ }^{1}$ Section for Outcomes Research, Center for Medical Statistics, Informatics, and Intelligent Systems, Medical University of Vienna, Spitalgasse 23, 1090 Vienna, Austria. ${ }^{2}$ LMU Munich, Department of Medical Information Processing, Biometry and Epidemiology (IBE), Chair of Public Health und Health Services Research, Marchioninistr. 17, 81377 Munich, Germany. ${ }^{3}$ Pettenkofer School of Public Health, Munich, Germany. ${ }^{4}$ Department of Medicine III, Division of Gastroenterology and Hepatology, Medical Nutrition Therapy and Dietetics, Vienna General Hospital, Währinger Gürtel 18-20, 1090 Vienna, Austria. ${ }^{5}$ Department of Medicine III, Division of Gastroenterology and Hepatology, Medical University of Vienna, Währinger Gürtel 18-20, 1090 Vienna, Austria.

Received: 10 September 2018 Accepted: 3 October 2019

Published online: 29 November 2019

\section{References}

1. Cederholm T, Barazzoni R, Austin P, Ballmer P, Biolo G, Bischoff SC, et al. ESPEN guidelines on definitions and terminology of clinical nutrition. Clin Nutr. 2017;36(1):49-64

2. Arends J, Bachmann P, Baracos V, Barthelemy N, Bertz H, Bozzetti F, et al. ESPEN guidelines on nutrition in cancer patients. Clin Nutr. 2017;36(1):11-48.

3. Bischoff SC, Boirie Y, Cederholm T, Chourdakis M, Cuerda C, Delzenne NM, et al. Towards a multidisciplinary approach to understand and manage obesity and related diseases. Clin Nutr. 2017;36(4):917-38.

4. Hakel-Smith N, Lewis NM. A standardized nutrition care process and language are essential components of a conceptual model to guide and document nutrition care and patient outcomes. J Am Diet Assoc. 2004; 104(12):1878-84.

5. Hakel-Smith N, Lewis NM, Eskridge KM. Orientation to nutrition care process standards improves nutrition care documentation by nutrition practitioners. J Am Diet Assoc. 2005;105(10):1582-9.

6. Writing Group of the Nutrition Care Process/Standardized Language C. Nutrition care process and model part I: the 2008 update. J Am Diet Assoc. 2008;108(7):1113-7.

7. Lacey K, Pritchett E. Nutrition care process and model: ADA adopts road map to quality care and outcomes management. J Am Diet Assoc. 2003; 103(8):1061-72. 
8. Directive 2011/24/EU of the European Parliament and of the Council of 9 March 2011 on the application of patients' rights in cross-border healthcare, OJ L 88(2011)

9. Yuill KA. Report on Knowledge and Perceived Use of a Nutrition Care Process \& Standardised Language by Dietitians in Europe [Internet]. European Federation of the Association of Dietitians (EFAD); 2012 [Available from: http://www.efad.org/media/1185/ncp__sl_report.pdf.

10. Gäbler G, Coenen M, Lycett D, Stamm T. Towards a standardized nutrition and dietetics terminology for clinical practice: an Austrian multicenter clinical documentation analysis based on the international classification of functioning, disability and health (ICF)-dietetics. Clin Nutr. 2019;38(2):791-9.

11. Gäbler GJ, Coenen M, Bolleurs C, Visser WK, Runia S, Heerkens YF, et al. Toward harmonization of the nutrition care process terminology and the international classification of functioning, disability and health-dietetics: results of a mapping exercise and implications for nutrition and dietetics practice and research. J Acad Nutr Diet. 2018;118(1):13-20 e13.

12. Enrione EB. Content validation of nutrition diagnoses. Top Clin Nutr. 2008; 23(4):306-19.

13. Rossi M, Campbell KL, Ferguson M. Implementation of the nutrition care process and international dietetics and nutrition terminology in a singlecenter hemodialysis unit: comparing paper vs electronic records. J Acad Nutr Diet. 2014;114(1):124-30.

14. Ritter-Gooder P, Lewis NM. Content validity of nutrition diagnostic term involuntary weight loss. J Am Diet Assoc. 2009;109(9):A22.

15. Ritter-Gooder PK, Lewis NM, Eskridge KM. Content validation of a standardized language diagnosis by certified specialists in Gerontological nutrition. J Am Diet Assoc. 2011;111(4):561-6.

16. Atkins $M$, Basualdo-Hammond $C$, Hotson B. Dietitians of C. Canadian perspectives on the nutrition care process and international dietetics and nutrition terminology. Can J Diet Pract Res. 2010;71(2):e18-20.

17. Vivanti A, Lewis J, O'Sullivan TA. The nutrition care process terminology: changes in perceptions, attitudes, knowledge and implementation amongst Australian dietitians after three years. Nutr Diet. 2018;75(1):87-97.

18. Vivanti A, O'Sullivan TA, Porter J, Hogg M. Successful long-term maintenance following nutrition care process terminology implementation across a state-wide health-care system. Nutr Diet. 2017; 74(4):372-80.

19. Gardner-Cardani J, Yonkoski D, Kerestes J. Nutrition care process implementation: a change management perspective. J Am Diet Assoc. 2007; 107(8):1429-33.

20. Lovestam E, Bostrom AM, Orrevall Y. Nutrition care process implementation: experiences in various dietetics environments in Sweden. J Acad Nutr Diet. 2017;117(11):1738-48.

21. Porter JM, Devine A, Vivanti A, Ferguson M, O'sullivan TA. Development of a nutrition care process implementation package for hospital dietetic departments. Nutr Dietetics. 2015;72(3):205-12.

22. Stamm TA, Cieza A, Coenen M, Machold KP, Nell VPK, Smolen JS, et al. Validating the international classification of functioning, disability and health comprehensive Core set for rheumatoid arthritis from the patient perspective: a qualitative study. Arthritis Rheum. 2005;53:431-9.

23. Cerniauskaite M, Quintas R, Boldt C, Raggi A, Cieza A, Bickenbach JE, et al. Systematic literature review on ICF from 2001 to 2009: its use, implementation and operationalisation. Disabil Rehabil. 2011;33(4):281-309.

24. Rauch A, Cieza A, Stucki G. How to apply the international classification of functioning, disability and health (ICF) for rehabilitation management in clinical practice. Eur J Phys Rehabil Med. 2008;44(3):329-42.

25. ICF Case Studies. ICF Research Branch; [cited 2018 April 20]. Available from: https://www.icf-research-branch.org/icf-case-studies.

26. Li J, Prodinger B, Reinhardt JD, Stucki G. Towards the system-wide implementation of the international classification of functioning, disability and health in routine practice: lessons from a pilot study in China. J Rehabil Med. 2016;48(6):502-7.

27. Appleby $\mathrm{H}$, Tempest $\mathrm{S}$. Using change management theory to implement the international classification of functioning, disability and health (ICF) in clinical practice. Br J Occup Ther. 2006:69(10):477-80.

28. Prodinger B, Scheel-Sailer A, Escorpizo R, Stucki G, Moderators UPIW, rapporteurs. European initiative for the application of the international classification of functioning, disability and health: development of clinical assessment schedules for specified rehabilitation services. Eur J Phys Rehabil Med. 2017;53(2):319-32.
29. Stucki G, Zampolini M, Juocevicius A, Negrini S, Christodoulou N. Practice, science and governance in interaction: European effort for the system-wide implementation of the international classification of functioning, disability and health (ICF) in physical and rehabilitation medicine. Eur J Phys Rehabil Med. 2017:53(2):299-307.

30. Tempest S, Harries P, Kilbride C, De Souza L. Enhanced clarity and holism: the outcome of implementing the ICF with an acute stroke multidisciplinary team in England. Disabil Rehabil. 2013;35(22):1921-5.

31. Tempest $\mathrm{S}$, Jefferson R. Engaging with clinicians to implement and evaluate the ICF in neurorehabilitation practice. NeuroRehabilitation. 2015:36(1):11-5.

32. Moore GF, Audrey S, Barker M, Bond L, Bonell C, Hardeman W, et al. Process evaluation of complex interventions: Medical Research Council guidance. BMJ. 2015:350:h1258.

33. Leeman J, Birken SA, Powell BJ, Rohweder C, Shea CM. Beyond "implementation strategies": classifying the full range of strategies used in implementation science and practice. Implement Sci. 2017;12(1):125.

34. Nilsen P. Making sense of implementation theories, models and frameworks. Implement Sci. 2015;10(1):53.

35. Improved Clinical Effectiveness through Behavioural Research G. Designing theoretically-informed implementation interventions. Implement Sci. 2006;1:4

36. Grol RP, Bosch MC, Hulscher ME, Eccles MP, Wensing M. Planning and studying improvement in patient care: the use of theoretical perspectives. Milbank Q. 2007:85(1):93-138.

37. Bhattacharyya O, Reeves S, Garfinkel S, Zwarenstein M. Designing theoretically-informed implementation interventions: fine in theory, but evidence of effectiveness in practice is needed. Implement Sci. 2006;1:5

38. Damschroder LJ, Aron DC, Keith RE, Kirsh SR, Alexander JA, Lowery JC. Fostering implementation of health services research findings into practice: a consolidated framework for advancing implementation science. Implement Sci. 2009:4:50

39. Keith RE, Crosson JC, O'Malley AS, Cromp D, Taylor EF. Using the consolidated framework for implementation research (CFIR) to produce actionable findings: a rapid-cycle evaluation approach to improving implementation. Implement Sci. 2017;12(1):15.

40. Tabak RG, Khoong EC, Chambers DA, Brownson RC. Bridging research and practice: models for dissemination and implementation research. Am J Prev Med. 2012:43(3):337-50.

41. Varsi C, Ekstedt M, Gammon D, Ruland CM. Using the consolidated framework for implementation research to identify barriers and facilitators for the implementation of an internet-based patient-provider communication Service in Five Settings: a qualitative study. J Med Internet Res. 2015;17(11):e262.

42. Kirk MA, Kelley C, Yankey N, Birken SA, Abadie B, Damschroder L. A systematic review of the use of the consolidated framework for implementation research. Implement Sci. 2016:11:72.

43. Luck J, Bowman C, York L, Midboe A, Taylor T, Gale R, et al. Multimethod evaluation of the VA's peer-to-peer toolkit for patient-centered medical home implementation. J Gen Intern Med. 2014;29(Suppl 2):S572-8.

44. Robins LS, Jackson JE, Green BB, Korngiebel D, Force RW, Baldwin LM. Barriers and facilitators to evidence-based blood pressure control in community practice. J Am Board Fam Med. 2013;26(5):539-57.

45. Damschroder LJ, Lowery JC. Evaluation of a large-scale weight management program using the consolidated framework for implementation research (CFIR). Implement Sci. 2013;8:51.

46. Stetler CB, Legro MW, Wallace CM, Bowman C, Guihan M, Hagedorn H, et al The role of formative evaluation in implementation research and the QUERI experience. J Gen Intern Med. 2006;21(S2).

47. Grol R, Grimshaw J. From best evidence to best practice: effective implementation of change in patients' care. Lancet. 2003;362(9391):1225-30.

48. Wensing M, Bosch M, Grol R. Developing and selecting interventions for translating knowledge to action. CMAJ. 2010;182(2):E85-8.

49. Grimshaw JM, Eccles MP, Lavis JN, Hill SJ, Squires JE. Knowledge translation of research findings. Implement Sci. 2012;7:50

50. Straus SE, Tetroe JM, Graham ID. Knowledge translation is the use of knowledge in health care decision making. J Clin Epidemiol. 2011;64(1):6-10.

51. Baker R, Camosso-Stefinovic J, Gillies C, Shaw EJ, Cheater F, Flottorp S, et al. Tailored interventions to overcome identified barriers to change: effects on professional practice and health care outcomes. Cochrane Database Syst Rev. 2010;3:CD005470

52. O'Brien MA, Rogers S, Jamtvedt G, Oxman AD, Odgaard-Jensen J, Kristoffersen DT, et al. Educational outreach visits: effects on professional 
practice and health care outcomes. Cochrane Database Syst Rev. 2007;4: CD000409.

53. Ivers N, Jamtvedt G, Flottorp S, Young JM, Odgaard-Jensen J, French SD, et al. Audit and feedback: effects on professional practice and healthcare outcomes. Cochrane Database Syst Rev. 2012;6:CD000259.

54. Ivers NM, Grimshaw JM, Jamtvedt G, Flottorp S, O'Brien MA, French SD, et al. Growing literature, stagnant science? Systematic review, metaregression and cumulative analysis of audit and feedback interventions in health care. J Gen Intern Med. 2014;29(11):1534-41.

55. Baker R, Camosso-Stefinovic J, Gillies C, Shaw EJ, Cheater F, Flottorp S, et al. Tailored interventions to address determinants of practice. Cochrane Database Syst Rev. 2015;4:CD005470.

56. Hoffmann TC, Glasziou PP, Boutron I, Milne R, Perera R, Moher D, et al. Better reporting of interventions: template for intervention description and replication (TIDieR) checklist and guide. BMJ. 2014;348:91687.

57. Proctor EK, Powell BJ, McMillen JC. Implementation strategies: recommendations for specifying and reporting. Implement Sci. 2013;8:139.

58. International classification of functioning, disability and health: ICF. Geneva: World Health Organization; 2001

59. Coenen M, Kus S, Rudolf K-D, Müller G, Berno S, Dereskewitz C, et al. Do patient-reported outcome measures capture functioning aspects and environmental factors important to individuals with injuries or disorders of the hand? J Hand Ther. 2013;26(4):332-42 quiz 42.

60. Stamm TA, Mattsson M, Mihai C, Stöcker J, Binder A, Bauernfeind B, et al. Concepts of functioning and health important to people with systemic sclerosis: a qualitative study in four European countries. Ann Rheum Dis. 2011:70(6):1074-9.

61. Gale NK, Heath G, Cameron E, Rashid S, Redwood S. Using the framework method for the analysis of qualitative data in multi-disciplinary health research. BMC Med Res Methodol. 2013;13:117.

62. Pope C, Ziebland S, Mays N. Qualitative research in health care: Analysing qualitative data. Br Med J. 2000;320:114-6.

63. Consolidated Framework for Implementation Research (CFIR): Tools and Templates. The Consolidated Framework for Implementation Research; [updated 2014 Oct 29 cited 2017 Sept 7]. Available from: https://cfirguide. org/tools/tools-and-templates/.

64. McDonald KM. Considering context in quality improvement interventions and implementation: concepts, frameworks, and application. Acad Pediatr. 2013;13(6 Suppl):S45-53.

65. Zoellner J, Van Horn L, Gleason PM, Boushey CJ. What is translational research? Concepts and applications in nutrition and dietetics. J Acad Nutr Diet. 2015;115(7):1057-71.

66. Birken SA, Powell BJ, Shea CM, Haines ER, Alexis Kirk M, Leeman J, et al. Criteria for selecting implementation science theories and frameworks: results from an international survey. Implement Sci. 2017;12(1):124.

67. Breimaier HE, Heckemann B, Halfens RJ, Lohrmann C. The consolidated framework for implementation research (CFIR): a useful theoretical framework for guiding and evaluating a guideline implementation process in a hospital-based nursing practice. BMC Nurs. 2015;14:43.

68. Clinton-McHarg T, Yoong SL, Tzelepis F, Regan T, Fielding A, Skelton E, et al. Psychometric properties of implementation measures for public health and community settings and mapping of constructs against the consolidated framework for implementation research: a systematic review. Implement Sci. 2016;11(1):148.

69. Flodgren G, Parmelli E, Doumit G, Gattellari M, O'Brien MA, Grimshaw J, et al. Local opinion leaders: effects on professional practice and health care outcomes. Cochrane Database Syst Rev. 2011;8:CD000125.

70. Colquhoun HL, Brehaut JC, Sales A, Ivers N, Grimshaw J, Michie S, et al. A systematic review of the use of theory in randomized controlled trials of audit and feedback. Implement Sci. 2013;8:66.

71. Forsetlund L, Bjorndal A, Rashidian A, Jamtvedt G, O'Brien MA, Wolf F, et al. Continuing education meetings and workshops: effects on professional practice and health care outcomes. Cochrane Database Syst Rev. 2009;2: CD003030.

72. Stetler CB, Legro MW, Wallace CM, Bowman C, Guihan M, Hagedorn H, et al. The role of formative evaluation in implementation research and the QUERI experience. J Gen Intern Med. 2006;21(Suppl 2):S1-8.

73. Schuntermann MF. The implementation of the international classification of functioning, disability and health in Germany: experiences and problems. Int J Rehabil Res. 2005;28(2):93-102.
74. Heerkens $\mathrm{YF}$, de Weerd M, Huber M, de Brouwer CP, van der Veen $\mathrm{S}$, Perenboom RJ, et al. Reconsideration ICF scheme. Disabil Rehabil. 2018; 40(1):121-2

75. Vreeman DJ, Richoz C. Possibilities and implications of using the ICF and other vocabulary standards in electronic health records. Physiother Res Int. 2015;20(4):210-9.

76. Ham C, Berwick D, Dixon J. Improving quality in the English NHS: a strategy for action [monograph online]. London: The King's Fund; 2016 [cited 2017 June 9]. Available from: www.kingsfund.org.uk/sites/default/files/field/field_ publication_file/Improving-quality-Kings-Fund-February-2016.pdf.

77. Damschroder LJ, Goodrich DE, Robinson CH, Fletcher CE, Lowery JC. A systematic exploration of differences in contextual factors related to implementing the MOVE! Weight management program in VA: a mixed methods study. BMC Health Serv Res. 2011;11:248.

78. Flottorp SA, Oxman AD, Krause J, Musila NR, Wensing M, Godycki-Cwirko M, et al. A checklist for identifying determinants of practice: a systematic review and synthesis of frameworks and taxonomies of factors that prevent or enable improvements in healthcare professional practice. Implement Sci. 2013:8:35

\section{Publisher's Note}

Springer Nature remains neutral with regard to jurisdictional claims in published maps and institutional affiliations.
Ready to submit your research? Choose BMC and benefit from:

- fast, convenient online submission

- thorough peer review by experienced researchers in your field

- rapid publication on acceptance

- support for research data, including large and complex data types

- gold Open Access which fosters wider collaboration and increased citations

- maximum visibility for your research: over $100 \mathrm{M}$ website views per year

At BMC, research is always in progress.

Learn more biomedcentral.com/submissions 